\title{
Materiały do historii altarystów kościoła Mariackiego w Krakowie w średniowieczu \\ Część 1: Kalendarz i nekrolog oraz katalog altarystów i benefaktorów
}

\begin{abstract}
Zarys treści: Publikacja zawiera krytyczną edycję wraz z komentarzem nieznanych dotąd, zachowanych w piętnastowiecznej redakcji, źródeł do dziejów domu altarystów kościoła Wniebowzięcia Panny Marii (Mariackiego) w Krakowie, kalendarza i nekrologu (wraz z notami nowożytnymi) oraz katalogu altarystów i benefaktorów do połowy XVI w.
\end{abstract}

Content outline: The publication contains a critical edition with commentary of so far unknown sources, surviving in the 15 th century redaction, concerning the history of the house of altarists of the Church of the Assumption of Virgin Mary in Cracow, the calendar and the necrology (with early modern notes) and the catalogue of altarists and benefactors until mid- $16^{\text {th }}$ century.

Słowa kluczowe: średniowieczny Kraków, kościół Mariacki, kler parafialny, nekrolog

Keywords: medieval Cracow, Church of the Assumption of Virgin Mary, parish clergy, necrology

W bogatym, liczącym ponad 3500 jednostek, zbiorze rękopisów Archiwum Narodowego w Krakowie, skatalogowanym jeszcze w początku XX w. przez zespół archiwistów pracujących pod kierunkiem ówczesnego dyrektora tej placówki, znakomitego mediewisty Stanisława Krzyżanowskiego (1865-1917)1', wydzielono osobny dział mieszczący Acta ecclesiarum et monasteriorum Cracoviensium. Spośród włączonych tam 240 woluminów ponad 30 zakupiono do Archiwum w 1892 r. za pieniądze wyasygnowane przez radę miejską; nabyto je od spadkobierców Wilhelma Gąsiorowskiego (1825-1892), bibliofila, kolekcjonera i wykładowcy geografii, historii oraz języka polskiego w Instytucie Technicznym w Krakowie². Gąsiorowski, obok

${ }^{1}$ Katalog Archiwum Aktów Dawnych Miasta Krakowa, t. II: Kraków. Rękopisy, nr 1-3568, [red. S. Krzyżanowski], Kraków 1915.

${ }^{2}$ W katalogu błędnie podano jednak, że rękopisy po W. Gąsiorowskim zostały zakupione w 1894 r., por. S. Krzyż a n o w s ki, Sprawozdanie archiwariusza za rok 1892, Kraków 1893, s. 2-3; M. S o k o ł o w s k i, Sprawozdania Komisji do Badania Historii Sztuki w Polsce 5, 1896, s. LIV; L. R ę g o r e w i c z, Historia Instytutu Technicznego w Krakowie, Kraków 1913, s. 131, 173; S. J. G ą s i o r o w s k i, Gąsiorowski Wilhelm, w: Polski słownik biograficzny, t. VII (1948-1958), s. 356. 
nieco starszych od siebie Ambrożego Grabowskiego (1782-1868) oraz Kaspra Meciszewskiego (1800-1881), był jednym z pionierów badań archiwalnych nad dawnym Krakowem. Opublikował kilka wartościowych prac, na czele z pierwszą monografią kościoła Mariackiego ${ }^{3}$. W jakich okolicznościach wszedł w posiadanie licznych średniowiecznych dokumentów oraz rękopisów, można obecnie snuć jedynie domysły. Najpewniej po prostu wypożyczał je z archiwów poszczególnych kościołów, o których pisał, i nie zdążył (bądź też nie zamierzał) ich oddać4. Pomiędzy nimi znajduje się bezcenny piętnastowieczny kodeks, pierwotnie oprawiony w pergaminowe karty zapisane tekstem hebrajskim, mieszczący m.in. kalendarz i nekrolog domu altarystów kościoła Mariackiego (rkps nr 3361). Jak dotąd rękopis ten nie wzbudzał większego zainteresowania ani stosunkowo licznych autorów zgłębiających dzieje krakowskiej fary (posiadającej status parafii od czasu sprowadzenia do Krakowa dominikanów w $1222 \mathrm{r}^{5}$ ) ani badaczy interesujących się dawną heortologią ${ }^{6}$. Uważna lektura pomieszczonych w nim not nekrologicznych, jak i samej części kalendarzowej, pozwala jednak, jak się okazuje, nie tylko na wejrzenie w nierozpoznaną dotąd historię instytucji domu altarystów mariackich, ale także na uzupełnienie dotychczasowej wiedzy o szeroko pojętej pamięci grupowej, nieograniczającej się do środowiska altarystów największego kościoła parafialnego Krakowa.

Rękopis mieszczący tytułowy zabytek to papierowy kodeks o wymiarach $31 \times 21,5 \mathrm{~cm}$, liczący 106 kart papierowych oraz 2 pergaminowe karty ochronne, stanowiące pierwotną oprawę. Na obecną oprawę, wykonaną przed 1915 r., składają się dwie deski częściowo oklejone brunatną skórą cielęcą, zamocowane do bloku za pomocą czterech zwięzów grzbietowych. Paginacja obejmująca 216 stron (wraz

${ }^{3}$ W. G ą s i o r o w s k i, Kościół archiprezbiteralny N.P. Maryi w Krakowie, Kraków 1878.

${ }^{4} \mathrm{Z}$ samego tylko archiwum kościoła Mariackiego W. Gąsiorowski wypożyczył 16 rękopisów, zob. Katalog, nr 3332, 3335, 3338, 3340-3341, 3361-3367, 3369-3372.

5 Rękopis ten wykorzystała jak dotąd jedynie H. Z a r e m s k a, Bractwa w średniowiecznym Krakowie. Studium form społecznych życia religijnego, Wrocław 1977, s. 71, przyp. 16, ustalając lata zgonu kilkudziesięciu osób wpisanych do księgi bractwa Panny Marii. Odnośnie do dziejów parafii Mariackiej aktualność wciąż zachowuje studium M. F ri e d b e rga, Założenie i początkowe dzieje kościoła N. Panny Marji w Krakowie (XIII-XV w.), Rocznik Krakowski 22, 1929, s. 1-31 (i odbitka, Kraków 1928). Organizację wewnętrzną świątyni najpełniej przedstawił E. D ł u g o p o ls k i, Katalog kościoła N. P. Maryi w Krakowie, Teka Grona Konserwatorów Galicji Zachodniej 6, 1906, s. 1-36. Wiele do życzenia pozostawia natomiast monografia E. P i w o w a r c z y k, Dzieje kościoła Mariackiego (XIII-XVI w.), Kraków 2000, która skupiła się na przemianach architektonicznych oraz wyposażeniu. Z nowszych prac warto odnotować obszerne rozprawy J. R a j m a n a: „Unsere liebe Fraue”. Wspólnota miasta i kościoła w Krakowie w XIV wieku, Średniowiecze Polskie i Powszechne 4 (8), 2012, s. 150-201 (o związkach miasta jako instytucji i mieszczan z parafią); Żebrak, sługa i rzemieślnik w elitarnym bractwie Najświętszej Marii Panny w Krakowie (XIV - pierwsza połowa XVI wieku), tamże 6 (10), 2014, s. 140-157; Rajcy krakowscy i członkowie ich rodzin w księdze zmarłych bractwa Najświętszej Marii Panny (połowa XIV - koniec XVI wieku), tamże 7 (11), 2015, s. 47-70 (pierwsze pełne opracowanie księgi brackiej wydanej przez J. M i t k o w s k i e g o, Księga zmarłych bractwa Panny Marii w Krakowie [wiek XIV-XVIII], Studia Historyczne 11, 1968, s. 71-95).

${ }^{6}$ Ze względów typologicznych nie uwzględnił go w swojej rozprawie H. W ą s o w i c z, Kalendarz ksiąg liturgicznych Krakowa do połowy 16. wieku. Studium chronologiczno-typologiczne, Lublin 1995. 
z kartami ochronnymi), naniesiona została ołówkiem najpewniej w XIX w. Introligator złożył ów kodeks z siedmiu składek w następującym układzie: I - nieregularny seksternion $(5+6$, s. 3-24); II - okternion $(8+8$, s. 25-56); III - okternion $(8+8$, s. 57-88); IV - okternion $(8+8$, s. $89-120) ; \mathrm{V}-$ nieregularny okternion (6+8, s. 121-146); VI - składka nieregularna, pierwotnie złożona z 9 bifoliów $(8+9$, s. 147-180); VII - okternion ( $8+8$, s. 181-212). Na papierze zidentyfikowano dwa filigrany. Pierwszy, przedstawiający głowę wołu z umieszczonym między rogami prętem zakończonym krzyżem i oplecionym przez węża z ukoronowaną głową skierowaną w prawą stronę, występuje tylko na kartach I składki. Franciszek Piekosiński rozpoznał ten znak w jednej z ksiąg krakowskiego sądu biskupiego z początku lat osiemdziesiątych XV w. ${ }^{7}$ Drugi znak również wyobraża głowę wołu z prętem między rogami, ale zwieńczonym czteropłatkowym kwiatem. Na pręcie osadzona została natomiast korona otwarta z pięcioma sterczynami, z których środkową zdobi heraldyczna lilia. Ten filigran występuje na kartach pozostałych składek (II-VII). Jak dotąd nie został niestety zidentyfikowany. Podobny, o tożsamych rozmiarach, aczkolwiek z pięciopłatkowym kwiatem wieńczącym pręt, odnotowano w rękopisach z terenu Austrii oraz południowych i środkowych Niemiec (Augsburg, Cadolzburg, Eichstätt, Graz, Innsbruck, Wallerstein) datowanych na pierwszą połowę lat siedemdziesiątych $\mathrm{XV} \mathrm{w.}{ }^{8}$ Nie jest więc wykluczone, że papier, na którym spisano zasadniczą część omawianego rękopisu, pochodził z importu. Natomiast z pewnością zakupiono go w tym samym czasie.

Teksty związane z domem altarystów znajdują się w składkach II-VII. Na wszystkich kartach tych składek widoczny jest schemat pisarski wykonany brunatnym atramentem. Od początku miały one stanowić całość. Pomijając późniejsze, nowożytne uzupełnienia, w partii średniowiecznej rękopis ten został spisany przez jednego pisarza, który przedstawił się na pierwszej karcie kalendarza-nekrologu (s. 25) jako Marcin z B. (Opus domini Martini de B.). Pierwotnie składki te były nieoprawione, o czym przypomina zabrudzenie dolnych części pierwszych kart z tekstem kalendarza-nekrologu. Składka I (zapisana dopiero w XVII w.) wraz z pergaminowymi kartami ochronnymi została dodana do pozostałych, jak się wydaje, jeszcze przed końcem XV w. Do takiego wniosku skłania, po pierwsze, datacja papieru, który w całym rękopisie pochodzi mniej więcej z tego samego czasu, lat osiemdziesiątych (składka I) lub siedemdziesiątych XV w. (składki II-VII); po drugie zaś, fakt, że karty ochronne, przycięte do formatu rękopisu, założone zostały przez introligatora za pierwszą i ostatnią składkę kodeksu (a więc dopiero po dodaniu składki I do pozostałych). Na kartach tych widoczne są fragmenty spisanego czarnym atramentem w trzech kolumnach tekstu hebrajskiego, pochodzące z Księgi Ezechiela: okładzina górna - kolumna prawa: Ez 27, 19-21, środkowa: Ez 29, 27-30, lewa: Ez 28, 2; okładzina tylna - kolumna prawa oraz tekst w górnej części karty: nieczytelne, kolumna środkowa: Ez 27, 22-25, kolumna lewa:

${ }^{7}$ F. P i e k o s i ń s k i, Wybór znaków wodnych z XV stulecia, z. 1, Kraków 1896, s. 19, tab. 106, nr 1091.

${ }^{8}$ Die Ochsenkopf- Wasserzeichen, opr. G. Piccard, t. I, Stuttgart 1966, s. 229, t. III, Stuttgart 1966, Abt. XV, nr 218. Błędną informację zamieszczono zatem w Katalogu Archiwum, s. 453, jakoby ,papier w całym rękopisie [był] z jednakowym znakiem wodnym”. 
Ez 27, 30-33 ${ }^{9}$. Mając na uwadze, że pisma hebrajskiego, kwadratowego, nie da się datować, posługując się tymi samymi kryteriami, które obowiązują w badaniach nad pismem łacińskim, w sprawie czasu powstania owych kart powiedzieć można, że spisano je na pewno przed końcem XV w. ${ }^{10}$

Korpus tekstów średniowiecznych pomieszczonych w rękopisie nr 3361 tworzą: tytułowy kalendarz-nekrolog (s. 25-87), relacja o założeniu domu altarystów i opis jego uposażenia oraz statuty (s. 89-120), kopia dyplomu rady krakowskiej z 31 XII 1397 r., mocą którego władze miejskie na prośbę altarystów objęły zarząd nad zamieszkiwanym przez nich domem (s. 121-124), officia domus (s. 126-128), a także katalog altarystów i benefaktorów (s. 137-157) ${ }^{11}$. Spisane zostały one, jak wyżej wzmiankowano, jedną ręką, przez pisarza, który przedstawił się jako Marcin z B. Należy go najpewniej identyfikować jako Marcina z Bochni, którego Długosz w księdze uposażeń diecezji krakowskiej odnotowuje jako altarystę ołtarza św. św. Piotra i Pawła w kościele Mariackim, znajdującego się pod patronatem rajców krakowskich, a także wikariusza w kościele katedralnym ${ }^{12}$. Wedle ustaleń Stanisława Kurasia opisy uposażeń kościołów parafialnych na potrzeby Liber beneficiorum redagowano w latach 1474-1480 ${ }^{13}$. Wtedy także, lub nieznacznie później, Marcin z Bochni rozpoczął prace nad przepisaniem grupy tekstów związanych z domem altarystów mariackich (najpewniej z lat siedemdziesiątych XV w. pochodzi wszak wykorzystany przezeń papier), kończąc je ok. 1484 r. (na ten właśnie rok datowana jest ostatnia wpisana przezeń nota nekrologiczna w kalendarzu). Dysponować musiał zaś starszym, niezachowanym dziś rękopisem, mieszczącym kalendarz i nekrolog, prowadzony w jakiejś postaci już od lat osiemdziesiątych-dziewięćdziesiątych XIV w., skoro najstarsze wpisy w nim pochodzą z lat 1382-1399. Z kolei relacja o założeniu domu, stanowiąca praefatio do statutów, powstała w 1437 r. ${ }^{14}$ Około pół wieku później wszystkie te teksty zostały przepisane z myślą zebrania w jednym rękopisie. Ten z kolei przed końcem XV w. oprawiono i wnoszono doń dalsze wpisy aż do początku lat siedemdziesiątych XVII w. ${ }^{15}$

W czasach Marcina z Bochni sama instytucja domu altarystów mariackich liczyła już blisko 100 lat, a jej „początki” należy wiązać ze stale i regularnie rozrastającą się służbą liturgiczną, sprawującą posługę przy kolejnych fundacjach ołtarzowych, nierzadko posiadających więcej niż jedno ministerium ${ }^{16}$. Około 1387 r. altaryści

9 Por. M. S t a r zy ń s ki, Najstarszy dokument hebrajski na ziemiach polskich (1485) i jego tłumaczenia, Roczniki Historyczne 83, 2017, s. 189.

${ }^{10}$ H. Z a r e m s k a, Żydzi w średniowiecznej Polsce. Gmina krakowska, Warszawa 2011, s. 58 , il. 5 .

11 Katalog Archiwum, nr 3361.

12 Joannis Długosz Liber beneficiorum dioecesis Cracoviensis, t. II (Opera omnia, t. VIII), wyd. A. Przezdziecki, Cracoviae 1864, s. 4.

${ }^{13}$ S. K u r a ś, Regestrum ecclesiae Cracoviensis. Studium nad powstaniem tzw. Liber beneficiorum Jana Długosza, Warszawa 1966, s. 40-45.

${ }^{14}$ Kraków, Archiwum Narodowe (dalej cyt.: ANK), rkps nr 3361, s. 89: Incipit prefacio in statuta domus altaristarum ecclesie Sancte Marie in Cracovia retro maccella carnificum in acie site anno Domini millesimo $\mathrm{CCCC}^{\circ} \mathrm{XXXVII.}$

15 Ostatni wpis w nekrologu nosi datę 1652, a ostatni wpis w katalogu altarystów - 1671 .

${ }^{16}$ Zob. E. P i w ow a r c zy k, Fundacje XIV-wiecznych ołtarzy w kościele Mariackim 
mariaccy mieszkali w niewielkim domu przylegającym do budynku szkoły parafialnej, znajdującym się w południowym narożu Małego Rynku i ulicy Poselskiej ${ }^{17}$. Dzięki legatowi Jana Schönthöra wysokości 80 grzywien szerokich groszy i zaangażowaniu jednego z kapłanów mariackich, Jakuba Silbera, zakupiony został wówczas od mieszczanina Mikołaja Beliczera i jego żony Katarzyny jednotraktowy, dwukondygnacyjny dom, stojący we wschodnim narożu Małego Rynku i ulicy Siennej, a zatem na tyłach fary ${ }^{18}$. W 1397 r. trzej altaryści (Piotr, Jan Tasso i Piotr z Tyczyna), pełniący służbę przy ołtarzach znajdujących się pod patronatem rady miejskiej, wraz z kaznodzieją Mikołajem Germerem, znanym już Jakubem Silberem oraz Szymonem, niegdyś rektorem szkoły parafialnej św. Anny, zwrócili się do władz Krakowa z prośbą o przejęcie przez miasto opieki nad wzmiankowanym domem, co też zostało potwierdzone osobnym dokumentem. Zwolniono ów dom, rzecz jasna, od wszelkich ciężarów miejskich, ale pod pewnymi warunkami. Miał bowiem odtąd służyć przede wszystkim kapłanom sprawującym posługę przy ołtarzach, których patronat należał do rady, a dopiero w dalszej kolejności - pozostałym. Każdy nowo przyjmowany altarysta został natomiast zobowiązany do zaopatrzenia się w instrument notarialny, obligujący go do przykładnego życia w tej korporacji, a w razie popadnięcia w zatarg $\mathrm{Z}$ większością mieszkańców - do jej opuszczenia ${ }^{19}$.

Z piętnastowiecznych legatów na rzecz domu altarystów wymienić można jeszcze przynajmniej cztery. W 1420 r. mieszczanin Jan Zebenwirt, zasiadający w latach 1419-1425 w radzie miejskiej, przekazał (wraz z rajcami starymi) altarystom 80 grzywien szerokich groszy na założenie ogrodu ${ }^{20}$. Pięć lat później mieszczka Eneda, wdowa po Mikołaju Münzschreiberze, zapisała w testamencie dominis altaristis - - in domo aciali retro macella commorantibus czynsz ziemski w wysokości 3 grzywien $^{21}$. Z kolei w 1426 r. altarysta Jan Schultis przekazał przed krakowskim sądem ławniczym własny dom położony za jatkami miejskimi ${ }^{22}$, raczej sąsiadujący z wyżej wymienionym niż stanowiący jego połowę, jak wskazywał niegdyś Edmund

w Krakowie i ich uposażenie do roku 1529, w: Charisteria Tito Górski oblata. Studia i rozprawy ofiarowane profesorowi Tytusowi Górskiemu, Kraków 2003, s. 199-217; t a ż, Fundacje XV-wiecznych ołtarzy w kościele Mariackim w Krakowie i ich uposażenie do roku 1529, Folia Historica Cracoviensia 10, 2008, s. 305-326.

17 ANK, rkps nr 3361, s. 114: Cum ante annos quinquaginta [licząc od 1437 r.] circum et circa altariste illo pro tempore qui fuerunt in domella scole Beate Virginis contigua e regione domus nostre prefate versus Novam civitatis Cracoviensis Valvam per annos et tempora uti fraters simul degentes unanimes erant in Domino feliciter constituti.

18 Tamże; ta sama nota na początku katalogu altarystów (zob. Aneks II). Por. W. K o m o rowski, Średniowieczne domy krakowskie (od lokacji miasta do połowy XVII wieku). Kamienice, pałace miejskie i rezydencje kanonicze. Trwałość modelu gotyckiego w nowożytności, Kraków 2014, s. 189, 203, 284, 293 (tam starsza literatura).

${ }_{19}$ Kodeks dyplomatyczny katedry krakowskiej ś. Wacława, t. II, wyd. F. Piekosiński, Kraków 1883, nr 325.

${ }^{20}$ ANK, rkps nr 3361, s. 116-117.

${ }^{21}$ Zbiór dokumentów katedry i diecezji krakowskiej, t. II, wyd. S. Kuraś, Lublin 1973, nr 257.

${ }^{22}$ Kraków, Archiwum Parafii Wniebowzięcia Najświętszej Panny Marii (Mariackiej), dok. perg. nr 17. 
Długopolski23. Wreszcie w 1433 r. biskup krakowski Zbigniew Oleśnicki zatwierdził fundację infirmerii dla altarystów (stubella cum camera eidem stubelle contigua iuncta in domo habitacionis honorabilium altaristarum), na co środki przekazał znany już Jan Zebenwirt ${ }^{24}$. Korporacja ta funkcjonowała bez większych zmian przez kolejne dwa stulecia, tj. do czasu założenia kolejnej, zrzeszającej penitencjarzy, czyli spowiedników tzw. dawnej fundacji, będących jednocześnie altarystami (od 1623 r.) ${ }^{25}$. Jej dzieje, podobnie jak i pozostałych zrzeszeń duchowieństwa działających przy farze Mariackiej (penitencjarze, gracjaliści, psałterzyści, mansjonarze), domagają się w przyszłości szczegółowego rozpoznania. W przypadku altarystów ważne jest zachowanie bezcennych średniowiecznych statutów, w zasadzie jedynych znanych dziś tego typu zabytków z naszych ziem ${ }^{26}$. Ich edycja krytyczna wraz z komentarzem znajdzie się w przygotowywanej drugiej części naszego artykułu.

Przedmiot niniejszej edycji: kalendarz-nekrolog domu alatrystów to zabytek bezspornie wyjątkowy dla poznania kręgu osób związanych z tą korporacją, zarówno benefaktorów, jak i jej członków. Do konstrukcji kalendarza wieczystego posłużył krakowski kalendarz kapitulny znany z trzynastowiecznego rękopisu Ms 209 przechowywanego w Archiwum Krakowskiej Kapituły Katedralnej (mieszczącego również rocznik kapitulny oraz katalog biskupów). Kalendarz umieszczony w naszym rękopisie, pisany kaligraficznie dwoma kolorami atramentu, czerwonego i czarnego, powtarza więc schemat graficzny kalendarza kapitulnego. Każdy miesiąc rozpoczyna ozdobny inicjał budowany z majuskulnych liter KL (Kalendae), poniżej znajdują się zaś informacje o liczbie dni danego miesiąca słonecznego i księżycowego (dies/ lunaciones). W schemacie pisarskim po lewej stronie (na każdej stronie rękopisu zajmowanej przez kalendarz) odrysowano pięć linii tworzących cztery wąskie kolumny. W tych umieszczono: 1) liczby złote (litterae aureae, I-XIX), wyznaczające daty nowiu przy zastosowaniu rachuby aleksandryjskiej, pisane czerwonym atramentem; 2) litery dzienne (litterae feriales) oznaczające poszczególne dni tygodnia, pisane czarnym atramentem (B-G) oraz litery niedzielne (litterae dominicales) pisane zawsze czerwonym atramentem (A); 3)-4) kalendarz rzymski, pisany czerwonym atramentem. Pozostałą część każdej strony (piąta kolumna) zajmuje kalendarz chrześcijański wraz z wpisami nekrologicznymi. Niekiedy dopisywano tam także informacje z zakresu komputu, jak miejsce dnia przestępnego 24 II (locus bissextilis), równonoc wiosenną 21 III (equinoccium), sedes epactarum 22 III i sedes concurrencium 24 III. Odnotowano również jeden embolizm 5 III (embolismus septimus anno XII), czyli miesiąc przestępny cyklu księżycowego wedle rachuby Bedańskiej. Co warte uwagi, uzupełnianie kalendarza kapitulnego o te ostatnie dane zarzucono wraz z końcem miesiąca marca - i tylko do końca marca znajdują się one w kalendarzu mariackim. Z uwagi na fakt, że kwestię typologii świąt pomieszczonych w kalendarzu przedstawiła już Zofia Kozłowska-Budkowa, nie będziemy powtarzać jej ustaleńn ${ }^{27}$. Porównując jednak

${ }^{23}$ E. D 1 ug op o ls k i, Katalog, s. 20.

${ }^{24}$ Zbiór dokumentów katedry i diecezji krakowskiej, t. II, nr 325.

${ }^{25}$ E. Dług o polski, Katalog, s. 21.

${ }^{26}$ S. K u r a ś, Statuty i przywileje bractwa kapłanów dekanatu zatorskiego 1378-1525, Polonia Sacra 7, 1955, s. 253-274.

${ }^{27}$ Najdawniejsze roczniki krakowskie i kalendarz, wyd. Z. Kozłowska-Budkowa, Monu- 
martyrologium tego kalendarza z publikowanym niżej zabytkiem, należy odnotować tylko dwa odstępstwa. Pod $15 \mathrm{X}$ umieszczono w kalendarzu mariackim obok wspomnienia św. Jadwigi wspomnienie sanctorum Maurorum, obchodzone w kręgu kolońskim, obecne poza tym jedynie w pochodzącym z połowy XI w. kalendarzu sakramentarium tynieckiego ${ }^{28}$. Warto też zauważyć, iż w kalendarzu kapitulnym pod tą datą znajduje się wspomnienie księżnej Jadwigi w rycie duplex. Informacja o nim została wciągnięta do tego rękopisu ręką datowaną na drugą połowę XIV w. ${ }^{29}$ Jest ona szczególnie ważna w kontekście wcześniejszych hipotez o istnieniu starszej kopii kalendarza mariackiego, datowanej przed końcem XIV w., a mieszczącej też wpisy nekrologiczne. Jeśli bowiem osoba odpowiedzialna za przepisanie martyrologium kapitulnego na potrzeby domu altarystów mariackich umieściła w nim wspomnienie św. Jadwigi, mogła to uczynić najwcześniej właśnie w drugiej połowie XIV w.

Z kolei pod 8 XII zamiast popularnego Conceptio Mariae wpisano do kalendarza mariackiego wspomnienie Eucharii episcopi. To ostatnie nie występuje w żadnym ze znanych polskich kalendarzy, włącznie z najstarszymi. Co prawda jedenastowieczny Kodeks Gertrudy notuje pod 10 XII Eulalie virginis, ale rozbieżność zapisów jest zbyt duża, aby przypuszczać pomyłkę pisarza ${ }^{30}$. Euchariusz, zmarły ok. 270 r., był pierwszym biskupem Trewiru ${ }^{31}$. Poza Trewirem jego wspomnienie w dniu 8 XII rejestrują liczne kalendarze niemieckie, m.in. z Goslaru, Konstancji, Monachium, Merseburga czy Spiry ${ }^{32}$. Omówione odstępstwa od martyrologium kapitulnego krakowskiego wskazują nie tylko na możliwe źródła autora kalendarza mariackiego, ale także stanowią o jego wyjątkowości na tle pozostałych znanych zabytków tego typu zachowanych w zbiorach polskich.

Noty nekrologiczne do 1484 r. wpisywała jedna ręka. Kontynuowano je następnie w stuleciach XVI (jedna ręka) oraz XVII (trzy ręce). Wśród tych najstarszych wyróżnić trzeba zwłaszcza nieznane dotąd zapiski dotyczące Jadwigi Andegaweńskiej, Władysława Jagiełły, Zofii Holszańskiej oraz biskupów krakowskich: Zbigniewa Oleśnickiego, Tomasza Strzempińskiego i Jana Lutka z Brzezia. Warta uwagi jest również informacja o zaćmieniu słońca w 1415 r., niezależnie potwierdzająca relację Długosza ${ }^{33}$.

Kalendarzem i nekrologiem domu altarystów mariackich jako pierwsza zainteresowała się Z. Kozłowska-Budkowa, gromadząc około połowy lat pięćdziesiątych

menta Poloniae historica, series nova, t. V, Warszawa 1978, s. XXIII-XXVII.

${ }^{28}$ Kalendarz sacramentarium tynieckiego. Martyrologium Bedae presbiteris, w: Chrolonolgia polska, red. B. Włodarski, Warszawa 1957, s. 211; Inwentarz rękopisów do połowy XVI wieku w zbiorach Biblioteki Narodowej, opr. J. Kaliszuk, S. Szyler, Warszawa 2012, s. 31 (BOZ 8).

${ }^{29}$ Kalendarz katedry krakowskiej, Monumenta Poloniae historica, series nova, t. V, s. 178.

${ }^{30}$ Modlitwy księżnej Gertrudy z Psałterza Egberta z Kalendarzem, wyd. M. H. Malewicz, B. Kürbis, Kraków 2002 (Monumenta sacra Polonorum, t. II), s. 114.

${ }^{31}$ Die Benediktinerabtei St. Eucharius-St. Matthias vor Trier, opr. P. Becker, Berlin 1996 (Germania sacra, Neue Folge, t. XXXIV/8), s. 385-388.

${ }^{32}$ H. G r o te fe n d, Zeitrechnung des deutschen Mittelalters und der Neuzeit, t. I, Hannover 1891, s. 95.

${ }^{33}$ M. H. M a lew i c z, Zjawiska przyrodnicze w relacjach dziejopisarzy polskiego średniowiecza, Wrocław 1980, s. 98. 
ubiegłego wieku materiały na potrzeby podręcznika chronologii polskiej. W opracowanym przez nią kalendarzu liturgicznym krakowskim znajduje się zresztą ślad wykorzystania tego zabytku, aczkolwiek w żaden sposób przez nią nieoznaczony. Otóż pod datą $15 \mathrm{X}$ autorka ta odnotowała nie tylko wspomnienie Jadwigi dziewicy, ale także świętych Maurów, podkreślając, że nie występuje ono w żadnym z pięciu kalendarzy wykorzystanych jako podstawa źródłowa ${ }^{34}$. Jak pamiętamy, jest ono obecne, obok sakramentarza tynieckiego, jedynie w kalendarzu mariackim. Do skopiowania tytułowego źródła w kwietniu 1957 r. oddelegowany (najpewniej przez Z. Budkową) został Marian Zwiercan, późniejszy wieloletni pracownik Działu Rękopisów Biblioteki Jagiellońskiej ${ }^{35}$. Z. Kozłowska-Budkowa brała na pewno udział w kolacjonowaniu tego odczytu z oryginałem, o czym z kolei świadczą jej odręczne noty na maszynopisie z tekstem kalendarza i nekrologu ${ }^{36}$. Nie jest też wykluczone, że przygotowywała jego osobne wydanie. Z rękopisu korzystała jeszcze w maju 1979 r., wpisując chwiejnym pismem w archiwalnej metryczce temat pracy: „Kalendarze krakowskie”.

Podejmując się wydania kalendarza, które w sposób wydatny poszerza możliwości badań nad świątynią mariacką i jej duchowieństwem, oparliśmy się na owym odczycie M. Zwiercana, skolacjonowanym przez Z. Kozłowską-Budkową. Odczyt ten został przez nas ponownie zweryfikowany, a także uzupełniony o pominiętą część stricte kalendarzową (liczby złote, litery niedzielne i dzienne, kalendarz rzymski). Wydanie nasze oparte jest na zasadach wyłożonych w instrukcji wydawniczej opracowanej pod kierunkiem Władysława Semkowicza ${ }^{37}$, a także na modelu wypracowanym przez Z. Kozłowską-Budkową przy publikacji kalendarza kapitulnego ${ }^{38}$. Wszystkie zapisy wykonane czerwonym atramentem zostały oddane czcionką pogrubioną, a dopiski późniejszych rąk ujęte w nawiasy ostre: ręka B z XVI w. <aaa>, C z XVII w. $<<$ aaa $>>$, D z XVII w. $<<<$ aaa $>>>$, E z XVII w. $<<<<$ aaa $>>>>$. W miarę możliwości staraliśmy się również objaśnić osoby odnotowane w nekrologu, ograniczając się jednak do najstarszej, średniowiecznej jego partii, pisanej podstawową ręką $\mathrm{A}^{39}$.

${ }^{34}$ Chronologia polska, s. 153.

35 ANK, rkps nr 3361, metryczka.

${ }^{36}$ Kraków, Archiwum Zakładu Nauk Pomocniczych Historii w Instytucie Historii Uniwersytetu Jagiellońskiego, maszynopis bez sygnatury, na obwolucie ręką Z. Budkowej: „Kalendarz Mariacki, koniec XV w. Arch[iwum] m[iasta] Kr[akowa] nr 3361. Skol[acjonowane] raz jeszcze z oryginałem. Kopia p[ana] Zwiercana - czerwiec 1957”.

37 Instrukcja wydawnicza dla średniowiecznych źródeł historycznych, Archiwum Komisji Historycznej PAU, t. XIV, Kraków 1930, s. 1-40.

38 Kalendarz katedry krakowskiej, s. 109-195.

39 W komentarzu używamy następujących skrótów: APM - Kraków, Archiwum Parafii Wniebowzięcia Najświętszej Panny Marii (Mariackiej); ASC - Acta scabinalia Cracoviensia 1365-1376 et 1390-1397, wyd. S. Krzyżanowski, Kraków 1904; BP - Bullarium Poloniae, t. VI, wyd. I. Sułkowska-Kuraś, S. Kuraś, współpr. P. Szczaniecki OSB, M. Kowalczyk, Romae 1998; CA - Cracovia artificum 1300-1500, wyd. J. Ptaśnik, Kraków 1917; CAS 1441-1450 Cracovia artificum supplementa. Teksty źródłowe do dziejów kultury i sztuki z archiwaliów kurialnych i kapitulnych w Krakowie 1441-1450, wyd. B. Przybyszewski, Kraków 1993; CDUJ - Codex diplomaticus Universitatis Studii Generalis Cracoviensis, t. I, Cracoviae 1870; KDKK - Kodeks dyplomatyczny katedry krakowskiej św. Wacława, cz. II, wyd. F. Piekosiński, Kraków 1883; KDMK - Kodeks dyplomatyczny miasta Krakowa, t. I-II, wyd. F. Piekosiński, Kraków 1879, 1882; KPPM - Księgi przyjęć do prawa miejskiego w Krakowie 1392-1506, 
Edycję postanowiliśmy uzupełnić o pomieszczony w tym samym rękopisie, wspomniany wyżej katalog altarystów i benefaktorów, który w swojej najstarszej części (do 1484 r.) pisany był również ręką Marcina z Bochni. Kilkunastu kolejnych pisarzy kontynuowało go do $1671 \mathrm{r}$. Zdecydowaliśmy się jednak opublikować tylko wpisy do połowy XVI w. Mniej więcej w tym czasie zmienił się charakter wnoszonych do niego not. Imię i datę zgonu zaczęto bowiem uzupełniać o dalsze informacje biograficzne, wskutek czego z jednowersowych zapisów przekształciły się one w obszerniejsze, niekiedy nawet całostronicowe, teksty narracyjne. Podobnie jak w przypadku kalendarza-nekrologu, staraliśmy się objaśnić osoby odnotowane w katalogu, również ograniczając się do najstarszej, średniowiecznej jego partii, pisanej ręką Marcina z Bochni, który zmarł w 1486 r. (tę informację odnotował już jego anonimowy kontynuator).

W przygotowywanej drugiej części artykułu zamierzamy pomieścić edycję znajdujących się w tym samym kodeksie statutów altarystów.

\section{TEKST ŹRÓDŁOWY}

I. Kalendarz i nekrolog domu altarystów kościoła Mariackiego w Krakowie

\section{Ianuarius habet XXXI dies, lunaciones XXX}

Infrascripti consules liberaverunt domum altaristarum, primus Andreas Wirsingi, secundus Nicolaus Bochner, tercius Johannes Piczczen, quartus Petrus Geytan, quintus Johannes Ederar, sextus Nicolaus Gemlich, septimus Nicolaus Stralicz, octavus in ordine Johan- $^{b}$ nes $\mathrm{Czo}^{\mathrm{e}} \mathrm{pchyn}^{2}$. Anime omnium fidelium requiescant in pace.

$\begin{array}{lll}1 & \text { III } & \text { A [I] Kl. } \\ 2 & & \text { B IIII [Non.] } \\ 3 & \text { XI } & \text { C III [Non.] }\end{array}$

$\begin{array}{lll}4 & & \text { D II [Non.] } \\ 5 & \text { XIX } & \text { E Non. }\end{array}$

Circumcisio Domini

Octava sancti Stephani

Octava sancti Johannis

Anno Domini $\mathrm{M}^{\circ} 4^{\circ}$ LXXVII obiit honestus vir magister Caspar de Dambnow ${ }^{3}$, specialis benefactor huius domus, cuius executores, eggregius vir magister Nicolaus decretorum doctor de Nissa ${ }^{4}$ et magister Bernardus collegiatus de ibidem $^{5}$, dederunt decretum pro domo altaristarum de inpressa.

\section{Octava sanctorum Innocentum}

Vigilia

wyd. K. Kaczmarczyk, Kraków 1893; LB II - Joannis Długosz, Liber beneficiorum dioecesis Cracoviensis, t. II: Ecclesiae parochiales, Cracoviae 1864; NKRK II - Najstarsze księgi i rachunki miasta Krakowa od r. 1300 do 1400, cz. II, wyd. F. Piekosiński, J. Szujski, Kraków 1878; Starz. - M. Starzyński, Krakowska rada miejska w średniowieczu, Kraków 2010; ZDKK - Zbiór dokumentów katedry i diecezji krakowskiej, cz. II, wyd. S. Kuraś, Lublin 1973. 
[s. 26] 6 VIII F VIII Id.

G VII Id.

$\begin{array}{lll}8 & \text { XVI } & \text { A VI Id. } \\ 9 & \mathbf{V} & \text { B V Id. } \\ 10 & & \text { C IIII Id. } \\ 11 & \text { XIII } & \text { D III Id. }\end{array}$

[s. 27] 12

13

$14 \mathbf{X}$

15

16 XVIII B XVII Kl.

17 VII C XVI KI.

[s. 28] 18

19

20

21

22

23
II

G XIX [KI.]

E II Id.

F I Id.

A XVIII Kl.

D XV KI.

E XIIII KI.

IIII F XIII KI.

G XII KI.

XII A XI KI.

I $\mathrm{B}$ X KI.
Epyphania Domini

Anno Domini $\mathrm{M}^{\circ} 4^{\circ}$ VIII dominica die post Epiphaniam [8 I] obiit dominus Jacobus Zilbercin, primus erector et fautor domus specialissimus ${ }^{6}$.

\section{Valentini episcopi}

$<<$ Anno Domini 1621 die 7 Ianuarii obiit honestus vir Valentinus Foltin, altarista et confrater domus. Requiescat in pace.>>

Pacientis episcopi confessoris

Juliani martyris

Pauli primi heremite

Archadii martyris

Octava Epyphanie

Anno Domini $\mathrm{M}^{\circ} 4^{\circ}$ XLVII dominus Johannes Skawinski obiit, frater domus ${ }^{7}$.

Felicis in pincis

$<<$ Anno Domini 1620 die 14 obiit honestus vir Johannes Radzicki, plebanus in Brzeszko, altarista sanctorum Anthonii, Dorotheae et Catherinae, confrater domus. Requiescat in pace. $>>$

Mauri et Macharii abbatum

$<<<$ Anno Domini 1629 obiit reverendus dominus Severinus Cromerus de Pilca, canonicus Scarbimiriensis, plebanus in Rokitno, confrater senior domus, specialis benefactor ecclesiae parochialis Beatae Mariae Virginis, qui pro poenitenciario mille florenos Polonicales legavit. Tempore sui senioratus cum fideli adiutore, reverendo domino Alberto Marzecki, eiusdem etiam domus confratre, domum in muris et tectis (sumptu parvo communitatis, fratrum vero compositione ad id sufficienti) laudabiliter reformavit cochlearque argenteum domui donavit. Requiescat in pace. Amen. $>>$ Marcelli pape et martyris

Anthonii abbatis ${ }^{c}$

Prisce virginis

Maurii $^{d}$ et Marthe

Fabiani et Sebastiani martyrum

Agnetis virginis

Vincencii levite et martyris

Emranciane virginis 


$\begin{array}{rrlll}\text { [s. 29] } 24 & & \text { C IX Kl. } & \text { Thimotei apostoli } \\ 25 & \text { IX } & \text { D VIII Kl. } & \text { Conversio sancti Pauli } \\ 26 & & \text { E VII Kl. } & \text { Policarpi episcopi } \\ 27 & \text { XVII } & \text { F VI Kl. } & \text { Johannis Crisostomi episcopi } \\ 28 & \text { VI } & \text { G V Kl. } & \text { Octava Agnetis } \\ 29 & & \text { A IIII Kl. } & \text { Valerii episcopi } \\ \text { [s. 30] } 30 & \text { XIIII } & \text { B III Kl. } & \text { Aldegundis virginis } \\ 31 & \text { III } & \text { C II Kl. } & \text { Vigilii episcopi }\end{array}$

Februarius habet XXVIII dies, lunaciones XIX [sic]

$\begin{array}{llll} & 1 & & \text { D Ve }[\text { Kl.] } \\ & & \text { XI } & \text { E IIII Non. } \\ 3 & \text { XIX } & \text { F III Non. } \\ {[\text { s. } 31]} & 4 & \text { VIII } & \text { G II Non. } \\ & & \\ & & \\ & & \\ 5 & & \text { A Non. } \\ 6 & \text { XVI } & \text { B VIII Id. } \\ 7 & \text { V } & \text { C VII Id. } \\ 8 & & \text { D VI Id. } \\ 9 & \text { XIII } & \text { E V Id. } \\ 10 & \text { II } & \text { F IIII Id. } \\ 11 & & \text { G III Id. } \\ 12 & \mathbf{X} & \text { A II Id. } \\ 13 & & \text { B I Id. }\end{array}$

Brigide virginis

Purificacio sancte Marie Virginis

Blasii episcopi et martyris

Eulalie virginis

$<<$ Anno Domini 1628 die 4 obiit honestus vir Andreas Włochowic, plebanus Vsuensis, altarista et confrater domus. $>>$

Agathe virginis et martyris

Vedasti et Amandi episcoporum

Augustini episcopi et martyris

Dyonisii et Emiliani martyrum

Appolonie virginis

Scolastice virginis

Desiderii episcopi et martyris

Susanne virginis

Juliane virginis ${ }^{f}$

Anno Domini $\mathrm{M}^{\circ}[\mathrm{CCC}] \mathrm{XCVI}$ obiit Hannus

Petirman $^{8}$ dominica Esto michi.

14 XVIII C XVI KI.

Valentini martyris

15 VII D XV KI.

Crathonis martyris

[s. 33] 16

E XIIII KI.

$17 \quad$ XV F XIII KI.

Juliane virginis

Polocronii episcopi et martyris

18 IIII G XII KI.

Galbini martyris

19 A XI KI.

Gaii episcopi

20 XII B X Kl.

21 I $\mathrm{C}$ IX KI.

Felicis episcopi

Simeonis episcopi et martyris

[s. 34] 22 D VIII Kl.

Kathedra sancti Petri. Ver oritur

23 VIII E VII KI.

24 F VI Kl.

25 XVII G V KI.

Mathie apostoli. Locus bisextilis

26 VI A IIII [KI.]

Aldegundis virginis

Nescoris episcopi et martyris

Anno Domini $\mathrm{M}^{\circ} 4$ XVI obiit dominus Nicolaus Gundrami, altarista et frater noster ${ }^{9}$.

Juliani martyris

[s. 35] 28

XIIII C II [KI.]

Romani abbatis 


\section{Marcius habet dies XXXI, lunaciones XXX}

$<<<$ Anno Domini 1632 obiit reverendus dominus Stanislaus Przezdziecki, plebanus Gdouiensis, confrater domus, specialis ecclesiae parochialis Beatae Mariae Virginis Cracoviensis benefactor, quia pro duobus poenitenciariis quattuor millia florenos Polonicales aliosque centum florenos Polonicales pro reparatione domus per manus exequutorum donavit. Requiescat in pace. Amen. $\gg>$

$\begin{array}{lll}1 & \text { III } & \text { D KI. Marcius [sic] } \\ 2 & & \text { E VI Non. } \\ 3 & \text { XI } & \text { F V Non. } \\ 4 & & \text { G IIII Non. }\end{array}$

Donati martyris

Simplicii pape

Emitherii et Celidonii martyrum

Lucii pape et martyris. Translacio sancti Venceslai

$\begin{array}{rll}{[s .36] 5} & \text { XIX } & \text { A III Non. } \\ 6 & \text { VIII } & \text { B II Non. }\end{array}$

Foce martyris. Embolismus VIIus anno XII

Victoris et Victorini martyrum

$<<<$ Anno Domini 1636 die 7 obiit honestus vir Martinus Gromkowic, sacristianus Beatae Mariae Virginis, altarista et confrater domus. $>>>$

C I Non.

Perpetue et Felicitatis virginum

$<<$ Anno Domini 1622 die 6 obiit honestus vir Albertus Kownaczki, decanus omnium Sanctorum Cracoviae, altarista et confrater domus, cochlear argenteum fratribus donavit. Requiescat in pace. $>>$

$\begin{array}{lll}8 & \text { XVI } & \text { D VIII Id. } \\ 9 & \text { V } & \text { E VII Id. } \\ 10 & & \text { F VI Id. } \\ 11 & \text { XIII } & {[\text { G] V Id. }} \\ 12 & \text { II } & \text { A IIII Id. }\end{array}$

Translacio sancti Viti

Gradii cum sociis

Allexandri martyris

Gregorii pape et confessoris

Anno Domini $\mathrm{M}^{\circ} 4^{\circ}$ XXXI obiit dominus Petrus Groth magnus benefactor ${ }^{10}$, qui donavit domui octo marcas grossorum census perpetui et alia, cui tenetur unusquisque fratrum in anniversario suo unam missam pro defunctis adimplere et alias singulis ebdomadis duas missas, videlicet unam $^{g}$ Beatae Virginis, aliam pro anima ipsius testatoris, et predictas duas missas complebit unus altaristarum, quem ordo tanget.
B III Id.
$14 \mathbf{X}$
C II Id.

Evfrosine virginis

Anno Domini $\mathrm{M}^{\circ} 4^{\circ}$ LVI dominus Stanislaus altarista in Bythtum, benefactor domus, decessit de hac vita ${ }^{11}$. 


\begin{tabular}{|c|c|c|c|}
\hline & 15 & & D I Id. \\
\hline & 16 & XVII & E XVII KI. \\
\hline [s. 38] & 17 & VII & F XVI Kl. \\
\hline & 18 & & G XV Kl. \\
\hline & 19 & $\mathbf{X V}$ & A XIIII KI. \\
\hline & 20 & IIII & B XIII KI. \\
\hline & 21 & & C XII KI. \\
\hline & 22 & XII & D XI KI. \\
\hline [s. 39] & 23 & I & E X Kl. \\
\hline & 24 & & F IX Kl. \\
\hline & 25 & IX & G VIII KI. \\
\hline & 26 & & A VII KI. \\
\hline & 27 & XVII & B VI Kl. \\
\hline & 28 & VI & C V Kl. \\
\hline [s. 40] & 29 & & D IIII Kl. \\
\hline & 30 & XIIII & E III Kl. \\
\hline & 31 & III & F II Kl. \\
\hline
\end{tabular}

Longini martyris

Ciriaci sociorumque eius

Gerdrudis virginis

Allexandri episcopi et martyris

Johannis heremite

Anno Domini M 4 IX dominus Romanus

Nicolaus decessit de hac vita, frater noster.

Guthberti episcopi

Benedicti abbatis. Equinoccium

Anno Domini $\mathrm{M}^{\circ} 4^{\circ}$ IX obiit dominus Petrus de sancta Anna altarista ${ }^{12}$.

\section{Sedes epactarum}

Teodrici episcopi

Anno Domini $\mathrm{M}^{\circ} 4^{\circ} \mathrm{LXXIIII}$ obiit venerabilis magister Michael de Crosna, decretorum doctor, frater domus et benefactor ${ }^{13}$.

$<$ Obiit anno Domini 1517 Jacobus Ko lce frater et magnus benefactor domus, relinquens pro comodo domus et fratrum 4 marcas annui census, ob hoc 4 obligavit fratres ad unam missam qualibet septimana.>

Felicis martyris. Sedes concurrencium Anunciacio Dominica et Passio

Ludgeri episcopi et confessoris

Resureccio Domini

Sixti pape

Eustasii abbatis

Quirini martyris

Balbine virginis

Anno Domini $\mathrm{M}^{\circ} 4^{\circ}[4] 5^{\circ}$ obiit Clauskesingir benefactor domus, tunc feria quarta ${ }^{14}$.

Aprilis habet dies XXX, lunaciones XXIX

Anno Domini $\mathrm{M}^{\circ} 45^{\circ} 5^{\circ}$ reverendus in Christo pater dominus Sbigneus miseracione Divina tituli sancte Prisce sancte Romane ecclesie presbiter cardinalis et episcopus Cracoviensis, anno cardinalatus sedecimo, pontificatus XXX secundo, vite vero 60 sexto, prima mensis Aprilis mortuus est ${ }^{15}$.

Ezechielis prophethe

Anno Domini $\mathrm{M}^{\circ} 4^{\circ} \mathrm{VII}$ feria sexta post festum Pasche obiit dominus Johannes Kyzeweter, confrater noster ${ }^{16}$. 
[s. 41] 3

B III Non.

4 XIX

C II Non.
$7 \quad$ V $\quad$ F VII Id.
Anno Domini $\mathrm{M}^{\circ} 445$ obiit dominus Mathias de Peyzer, confrater domus ${ }^{17}$.

Theodosie virginis

$<<<$ Anno Domini 1638 obiit reverendus dominus Johannes Gaudentius, confrater senior domus, decanus et plebanus Wolbramensis [sic], cochlear parvum argenteum et cantarum etiam parvum staneum fratribus exequutores reddiderunt. $>>>$

\section{Ambrosii episcopi et confessoris}

$<<$ Anno Domini 1635 die 3 Aprilis obiit admodum reverendus dominus Joannes Stephanski, canonicus Sendomiriensis, Piekoszouiensis plebanus, vir exterarum nationum peregrinatione et linguarum noticia clarus, illustribus in nostro Regno personis ob morum elegantiam apprime clarus, domus huius benefactor memorabilis, utpote qui et cohlear argenteum et cantharum staneum pro communitate donavit et hortum plantis et arboribus fructiferis coemptis auxit ac insuper florenos Polonicales 30 legavit. Capellam Waltkonum in ecclesia Beatae Mariae Virginis racione altaris compassionis Beatae Mariae Virginis secundi ministerii, cuius possesor fuit, ille idem reformavit sumptu proprio. Certam summam pro duobus studiosis Casimiriae inscripsit. Sit memoria ilius in benedictione.>>

Marcianne virginis

Sixti pape

Anno Domini $\mathrm{M}^{\circ} 4^{\circ} \mathrm{XL}$ obiit Mathias Huet$\operatorname{ter}^{18}$, pro cuius anima et fratris ipsius Nicolai $\mathrm{Hu}^{e}$ tter tenemur legere duas missas in ipsius anniversario, quas explebunt lectores ordinarii, quia horum pecuniis Biblia maior comparata est, videlicet pro centum florenis.

$<$ Anno Domini 1516 obiit Johannes Sommerfelt, frater et benefactor, qui legavit pro necessitate domus duas ampullas argenteas inauratas.>

Elesippi confessoris

Anno Domini $\mathrm{M}^{\circ} 4^{\circ} \mathrm{LVIII}$ obiit dominus Daniel, confrater domus et benefactor specialis ${ }^{19}$.

Eodem die $\mathrm{M}^{\circ} 4^{\circ} \mathrm{LXV}$ obiit dominus Martinus Strik de Medzwno, confrater domus ${ }^{20}$. 
G VI Id.

$\begin{array}{rlll}{[s .42]} & 9 & \text { XIII } & \text { A V Id. } \\ 10 & \text { II } & \text { B III Id. } \\ & & \text { C III Id. } \\ & & & \\ 11 & \text { X } & \text { D II Id. } \\ 13 & & \text { E I Id. } \\ 14 & \text { XVIII } & \text { F XVIII KI. } \\ & \text { X XVII KI. }\end{array}$

16

$17 \quad \mathbf{X V}$

A XVI Kl.

18 IIII

B XV Kl.

C XIIII KI.

19

D XIII KI.

20 XII E XII KI.

[s. 44] 21 I $\quad$ F XI Kl.

22 G X Kl.

23 IX A IX Kl.

24

25 XVIII C VII KI.

26

[s. 45] 27

28

XIII F IIII KI.

29 III G III KI.

$30 \quad$ A II KI.
Prochorii diaconi et martyris

Anno Domini $\mathrm{M}^{\circ} 484$ obiit dominus Johannes Andree alias Czeyskendorf ${ }^{21}$, confrater domus, octava mensis Aprilis, id est feria quinta ante dominicam Palmarum.

Anthonii martyris

Sanctus Stanislaus Cracoviensis episcopus interfectus est.

Julii episcopi

Evfemie virginis

Tiburcii, Maximi et Valeriani martyrum

Maronis martyris

Anno Domini $\mathrm{M}^{\circ} 4^{\circ}$ XXXVI obiit dominus

Petrus de Ticzin dictus Decanus ${ }^{22}$, frater domus.

Calixti martyris

Petri diaconi

Eleutherii martyris

Genesii martyris

Anno Domini $\mathrm{M}^{\circ} 4^{\circ} 7^{\circ}$ nono obiit dominus

Paulus de Wyasd $^{23}$, frater domus.

Dedicacio ecclesie sancti Wenceslai

Symeonis episcopi

Gaii pape

Anno Domini $\mathrm{M}^{\circ} 4^{\circ} 76$ Johannes Luce de Cracovia ${ }^{24}$ frater et benefactor domus obiit.

Adalberti episcopi et martyris, Georgii martyris

Allexandri

Marci ewangeliste. Letania maior

Anno Domini $\mathrm{M}^{\circ} \mathrm{CCC}^{\circ} \mathrm{XC}$ obiit Katherina Beliczynne ${ }^{25}$.

Marcelli pape

Anastasii pape

Anno Domini $\mathrm{M}^{\circ} 4^{\circ} \mathrm{LXVII}^{\circ}$ obiit dominus Allexander de Dambicza, frater domus.

Vitalis martyris

Agapiti et Secundini martyris

Quintini episcopi

Anno Domini $\mathrm{M}^{\circ} 4^{\circ} \mathrm{LXXV}$ ultima mensis

Aprilis obiit honorabilis dominus Gregorius plebanus de Czeskowicze, confrater et benefactor domus, quia pro fabrica dedit quinque 
marcas et duos cifos ligneos cum modico argento reformatos.

\section{Maius habet dies XXXI, lunaciones XXX}

$\begin{array}{rll}1 & \text { XI } & \text { B KI. Maii } \\ {[s .46] 2} & & \text { C VI Non. } \\ & & \\ 3 & \text { XIX } & \text { D V Non. } \\ 4 & \text { VIII } & \text { E IIII Non. } \\ 5 & & \text { F III Non. }\end{array}$

6 XVI G II Non.

7 V A Non.

[s. 47$] 8$

$\begin{array}{lll}9 & \text { XIII } & \text { C VII Id. } \\ 10 & \text { II } & \text { D VI Id. } \\ 11 & & \text { E V Id. }\end{array}$

$12 \mathrm{X}$ F IIII Id.

13 G III Id.
Philippi et Jacobi apostolorum

Anastasii episcopi, $<$ Sigismundi $>i$

Anno Domini M 444 obiit dominus Stanislaus lector capelle aput sanctum Petrum.

Invencio sancte Crucis

Floriani martyris

Ascensio Domini, Gothardi episcopi et confessoris

Anno Domini Mo 4 LIIII dominus Clemens altarista beatorum Petri et Pauli, frater et benefactor domus, transivit de hoc mundo.

\section{Johannis ante Latinam Portam}

Juvenalis martyris

Canonizacio sancti Stanislai episcopi et martyris

Anno Domini $\mathrm{M}^{\circ} 4^{\circ}$ ut supra obiit Petrus

Kaldherberg ${ }^{26}$.

Translacio sancti Nicolai

Gordiani et Epimachi martyrum

Domiciani episcopi

Anno Domini $\mathrm{M}^{\circ} 4^{\circ} \mathrm{LVII}^{\circ}$ obiit dominus Nicolaus Capella, confrater et benefactor domus ${ }^{27}$. Nerei et Achilei, Pancracii martyrum

Servacii episcopi et confessoris

Anno Domini $\mathrm{M}^{\circ} 4^{\circ} \mathrm{LX}$ obiit Anna Florianen benefactrix domus.

Bonifacii martyris

Descensio Sancti Spiritus

Vincencii et Peregrini martyrum

Torpetis martyris

Anno Domini $\mathrm{M}^{\mathrm{o}} 4^{\circ} \mathrm{LXIII}$ obiit dominus Johannes Bartosch, frater et benefactor domus ${ }^{28}$.

18 IIII E XV KI.

19 F XIIII KI.

[s. 49] 20 XII G XIII Kl.

21 I A XII KI.

22 B XI KI.

Marci pape

Potenciane virginis

Basilie virginis

Helene

Faustini confessoris

Anno Domini $\mathrm{M}^{\circ} 4^{\circ}$ XXXI obiit dominus Nicolaus Kerber, altarista beatorum Petri et Pauli, confrater domus ${ }^{29}$.

23 IX C X KI.

Desiderii episcopi 
D IX KI.

25 XVII E VIII KI.

[s. 50] 26 VI $\quad$ F VII Kl.

27 G VI Kl.

28 XIIII A V Kl.

29 III B IIII KI.

$30 \quad$ C III KI.

31 IX D II KI.
Donaciani et Rogaciani martyrum

Anno Domini $\mathrm{M}^{\circ} 4^{\circ} 7^{\circ}$ primo, XX quarta Maii mensis, reverendus pater dominus Johannes Luthkonis de Brzezye, utriusque iuris doctor, episcopus Cracoviensis obiit, videlicet feria sexta ante Urbani pape et martyris ${ }^{30}$.

Urbani pape et martyris

Augustini episcopi et martyris

Julii episcopi

Germani episcopi

Anno Domini $\mathrm{M}^{\circ} 4^{\circ}$ XLIIII obiit Katherina coca domus.

Maximini episcopi

Anno Domini $\mathrm{M}^{\circ} 4^{\circ} \mathrm{LX}$ obiit dominus Nicolaus de Gleywicz, frater et benefactor domus. In eius aniversario lector ordinarius secundus in numero legat unam missam pro sacerdote et alii fratres inponant collectam.

Felicis pape

Anno Domini $\mathrm{M}^{\circ} \mathrm{CCC}[\mathrm{C}]^{\circ} \mathrm{VII}$ obiit dominus Johannes Scho ${ }^{e}$ tor $^{31}$, fundator et benefactor domus altaristarum.

Petronelle virginis

Anno Domini $\mathrm{M}^{\circ} 4^{\circ}$ XXXIIII in die sancte Petronelle virginis, tunc feria secunda infra octavas Corporis Christi, obiit serenissimus princeps et dominus, dominus Wladislaus rex Polonie, fidelis defensor Ecclesie et pius pater, amator et tutor cleri $^{32}$. Requiescat in pace.

Anno Domini $\mathrm{M}^{\circ} 4^{\circ}[\mathrm{X}] \mathrm{VII}$ obiit Caspar Krugel $^{33}$.

2 XIX F IIII KI.

Marcellini et Petri martyrum

Anno Domini $\mathrm{M}^{\circ} 4^{\circ}$ XLIII obiit honestus vir Johannes Zebenwirt consul, magnus benefactor et ampliator istius domus ${ }^{34}$. Requiescat.

3 VIII G III KI. Pergentini et Laurentini martyrum Anno Domini $\mathrm{M}^{\circ} 4^{\circ}$ XXXIX obiit dominus Nicolaus Cypsar, frater domus ${ }^{35}$.

$\begin{array}{lll}4 & \text { XVI } & \text { A II Kl. } \\ 5 & \text { V } & \text { B Non. }\end{array}$

Cyrini episcopi et martyris Bonifacii episcopi sociorumque eius Anno Domini $\mathrm{M}^{\circ} 4^{\circ} \mathrm{LXV}$ obiit Petrus de $\mathrm{Bec}^{36}$, magnus benefactor domus. 

[s. 52] 6
C VIII Id.

7 XIII D VII Id.

8 II E VI Id.

9 F V Id.

$10 \mathrm{X}$ G IIII Id.

11 A III Id.

[s. 53] 12 XVIII B II Id.

13 VII C I Id.

14 D XVIII KI.

15 XV E XVII KI.

16 IIII F XVI KI.

17 G XV Kl.
Anno Domini $\mathrm{M}^{\circ} 4^{\circ}$ XLIII fuit in Cracovia terre motus magnus in die Bonifacii ${ }^{37} .{ }^{j}$ Terre motus Cracoviae anno 1443..$^{-j}$

\section{Vincencii episcopi et martyris}

Anno Domini $\mathrm{M}^{\circ} 4^{\circ}$ LIX obiit honestus vir Johannes Tesznar, consul et benefactor domus $^{38}$.

Celestini et Luciani martyrum

$14 \times 5$ erat totalis eclipsis in Sole 7 Iunii hora $\mathrm{XI}^{39}$.

Medardi et Gildardi episcoporum

Primi et Feliciani martyrum

Anno Domini $\mathrm{M}^{\circ} 4^{\circ} 4^{\circ} 5^{\circ}$ obiit dominus Nicolaus Laudate, lector missarum, benefactor domus.

Basilidis, Tripodis et Mandalis martyrum

Barnabe apostoli

Basilidis, Cirini, Naboris et Nazarii martyrum Filicule virginis, Anthonii confessoris

Ruffi et Valerii martyrum

Viti et Modesti, Crescencie martyrum

Aurei et Justini martyrum

CCLXII martyrum

Anno Domini $\mathrm{M}^{\circ} 4^{\circ} \mathrm{LXX}$ sexto, X7 die mensis Iunii obiit dominus Johannes sacristianus, id est feria secunda post Viti infra octavas Corporis $\mathrm{Christi}^{40}$. Requiescat in pace. Amen.

Marci et Marcelliani martyrum

Gervasii et Prothasii martyrum

Nouati martyris

Albani martyris

$<<<<$ Anno 1648 die 21 Iunii obiit reverendus Albertus Marzecki, senioris munus tenens. Quid domui praestiterit, vide infra in cathalogo fratrum domus mortuorum, post statuta et cathalogum confratrum domus mortuorum ${ }^{41}$. $>>>$

Albini martyris

Vigilia

Nativitas sancti Johannis Baptiste

Gallicani martyris

Johannis et Pauli martyrum

Wladislai confessoris regis Vngarie

Vigilia

Petri et Pauli apostolorum 

[s. 56$] 30$
F II Kl.

Commemoracio sancti Pauli apostoli

Anno Domini $\mathrm{M}^{\circ}[\mathrm{C}] \mathrm{CCC}^{\circ}$ obiit dominus Geyseler, confrater domus ${ }^{42}$.

\section{Iulius habet dies XXXI, lunaciones XXX}

$\begin{array}{cccc}1 & \text { XIX } & \text { G KI. Iulius } \\ 2 & \text { VIII } & \text { A VI Non. } \\ 3 & & \text { B V Non. } \\ & & & \\ 4 & \text { XVI } & \text { C IIII Non. } \\ & & \\ \text { [s. 57] } 5 & \mathbf{V} & \text { D III Non. } \\ & & \\ & & \\ 6 & & \text { E II Non. } \\ & & \\ & & \\ 7 & & \text { XIII } & \text { F Non. } \\ 8 & \text { II } & \text { G VIII Id. } \\ & & \\ 9 & & \text { A VII Id. } \\ 10 & \text { X } & \text { B VI Id. } \\ 11 & & \text { C V Id. } \\ 12 & \text { XVIII } & \text { D IIII Id. }\end{array}$

Octava sancti Johannis Baptiste

Processi et Martiniani martyrum, Visitacio Sancte Marie

Anno Domini $\mathrm{M}^{\circ} 4^{\circ}$ LXXXII obiit dominus Georgius de Wincyg, confrater et benefactor domus $^{43}$.

Odalrici episcopi et confessoris

$<$ Petrus Scheps magnus benefactor domus nostre, qui eo vivente coquinam nostram ex fundo cum camino erexit.>

Dominici martyris

Anno Domini $\mathrm{M}^{\circ} 4^{\circ}$ LXII dominus Nicolaus Ympner frater domus et benefactor sublatus est.

\section{Octava apostolorum Petri et Pauli}

Anno Domini $\mathrm{M}^{\circ} 483$ frater domus dominus $\mathrm{N}$ [icolaus] cantor et altarista sancti Johannis Baptiste in capella ad sanctam Barbaram debitum suum persolvit. Requiescat in pace.

Villibardi confessoris

Kyliani episcopi sociorumque eius

Anno Domini $\mathrm{M}^{\circ} 4^{\circ}$ XXXVIII obiit dominus Nicolaus Falkenberg, altarista et frater domus ${ }^{44}$. Cirilli episcopi

\section{Fratrum}

Translacio sancti Benedicti abbatis

Felicis, Naboris martyrum

Anno Domini $\mathrm{M}^{\circ} 4$ VII obiit honesta Katherina Kranchin ${ }^{45}$.

$<<<$ Anno Domini 1637 obiit reverendus dominus Martinus Wolbram, plebanus in Dzierzazna, confrater senior domus, specialis benefactor domus, quia pro mensa communi mille florenos Polonicales testamentaliter legavit, cochlear argenteum cantarumque staneum fratribus donavit. Requiescat in pace. $>>$

$\begin{array}{lll}13 & \text { VII } & \text { E III Id. } \\ 14 & & \text { F II Id. } \\ 15 & \text { XV } & \text { G I Id. } \\ 16 & \text { IIII } & \text { A XVIII KI. }\end{array}$

Margarethe virginis

Foce martyris

Divisio apostolorum

Hylarii martyris 
Allexii confesoris

Anno Domini $\mathrm{M}^{\circ} \mathrm{CCC}^{\circ} \mathrm{XC}$ nono obiit sere-

$\begin{array}{lll}18 & \text { XII } & \text { C XV Kl. } \\ 19 & \text { X } & \text { D XIIII KI. } \\ 20 & & \text { E XIII Kl. } \\ 21 & \text { XIIII } & \text { F XII Kl. }\end{array}$
nissima princeps domina Hedwigis regina ${ }^{46}$. Arnulphi episcopi

Arsenii abbatis

Sabini, Maximini, Juliani martyrum

Praxedis virginis

Anno Domini $\mathrm{M}^{\circ} 4^{\circ}$ XXII obiit Nicolaus Cromer, magnus benefactor domus altaristarum ${ }^{47}$. Eodem die obiit dominus Gotfridus, frater et benefactor domus anno Domini $\mathrm{M}^{\circ} 4$ LIII.

$22 \quad$ G XI Kl.

[s. 60] $23 \quad$ XVII A X Kl.

24 VI B IX KI.

XIX
A III Kl.
B II KI.

Marie Magdalene $^{k}$

Appollinaris episcopi et martyris

Vigilia

Anno Domini $\mathrm{M}^{\circ} 4^{\circ} \mathrm{XXXV}$ obiit dominus Martinus altarista, frater domus.

\section{Jacobi apostoli, Christofori martyris}

Jacincti martyris

Hermolai presbiteri

Panthaleonis martyris

Felicis, Simplicii, Faustini, Beatricis, Marthe hospite Christi

Abdon et Sennes martyrum

Germani confessoris

Augustus habet dies XXXI, lunaciones XXIX

$\begin{array}{rlll} & \text { VIII } & \text { C KI. Augu } \\ 2 & \text { XVI } & \text { D IIII Non. } \\ \text { [s. 62] } 3 & \text { V } & \text { E III Non. } \\ 4 & & \text { F II Non. } \\ & & \\ & & \\ & & \text { XIII } & \text { G I Non. } \\ 6 & \text { II } & \text { A VIII Id. } \\ 7 & & \text { B VII Id. } \\ & & \\ & & \\ 8 & \mathbf{X} & \text { C VI Id. } \\ \text { [s. 63] } 9 & & \text { D V Id. }\end{array}$

Ad vincula Petri apostoli

Stephani pape et martyris

Invencio sancti Stephani prothomartyris

Justini presbiteri

Anno Domini $\mathrm{M}^{\circ} 4^{\circ} \mathrm{LV}$ magister N[icolaus] $\mathrm{Ho}^{\mathrm{e}}$ wer, licenciatus in theologia, altarista et frater domus obiit ${ }^{48}$.

\section{Dominici confessoris}

Sixti pape et martyris

Donati episcopi et martyris, Affre martyris Anno Domini $\mathrm{M}^{\circ} 4^{\circ} \mathrm{XXX}$ obiit dominus Nicolaus Rol, altarista et frater domus ${ }^{49}$. Ciriaci martyris sociorumque eius

\section{Vigilia}

$<<<$ Anno Domini 1626 die 9 obiit honestus vir Albertus Woiasz, plebanus Łetkouiensis, altarista et confrater domus. $>>>$ $<<<<$ Anno Domini 1652 die 9 Augusti reverendus Petrus Redkowic obiit, confrater 


$\begin{array}{lll}10 & \text { XVIII } & \text { E IIII Id. } \\ 11 & \text { VII } & \text { F III Id. } \\ 12 & & \text { G II Id. } \\ 13 & \text { XV } & \text { A I Id. } \\ 14 & \text { IIII } & \text { B XVIII KI. }\end{array}$

$\begin{array}{rlll}{[s .64]} & 15 & & \text { C XVII KI. } \\ 16 & \text { XII } & \text { D XVI KI. } \\ 17 & \text { I } & \text { E XV Kl. } \\ 18 & & \text { F XIIII KI. } \\ 19 & \text { IX } & \text { G XIII KI. } \\ 20 & & \text { A XII Kl. } \\ \text { [s. 65] } 21 & \text { XVII } & \text { B XI Kl. } \\ 22 & \text { VI } & \text { C X KI. } \\ 23 & & \text { D IX KI. } \\ 24 & \text { XIIII } & \text { E VIII KI. } \\ 25 & \text { III } & \text { F VII Kl. } \\ 26 & & \text { G VI KI. } \\ & & \\ {[s .66]} & \text { XI } & \text { A V KI. }\end{array}$

28 XIX B IIII KI.

29 C III KI.

30 VIII D III Kl. [sic]

31 E II Kl. domus. Quid beneficii domui fecerit, vide inferius in cathalogo confratrum domus mortuorum ${ }^{41}$. $>>>>$

\section{Laurencii martyris}

Tyburcii martyris

Enphil martyris diaconi

Ipoliti martyris sociorumque eius

Vigilia

$<<<$ Anno Domini 1651 die 14 Augusti, media nocte, admodum reverendus dominus Petrus Sasin, iuris utriusque doctor, confrater domus obiit. Quid boni domui fecerit, inferius in cathalogo mortuorum confratrum patet ${ }^{4 l}$. >>>> Assumpcio Sancte Marie Virginis

Ursacii confessoris

Octava sancti Laurencii

Agapiti martyris

Magni martyris

Stephani regis Vngarie

Privati martyris

Octava Sancte Marie

Vigilia

Bartholomei apostoli

Genesii martyris

Herenci et Habundi martyrum

Ruphi martyris

Anno Domini $\mathrm{M}^{\circ} 4^{\circ}$ LIX magister Stephanus Leypniger frater domus obiit ${ }^{50}$. Magnus benefactor, qui legavit domui altaristarum quatuor marcas perpetui census in duabus macellis carnificum.

Augustini episcopi et confessoris

Decollacio sancti Johannis Baptiste

Felicis et Adaucti martyrum

Paulini episcopi et confessoris

September habet dies XXX, lunaciones XXX

[s. 67] $1 \quad$ XVI F Kl. Septembris Egidii abbatis

Anno Domini [M CCC?] XC obiit dominus

Wenceslaus predicator, frater domus.

2 V G IIII Non.

Justi episcopi

Anno Domini $\mathrm{M}^{\circ} 4^{\circ} 3^{\circ}$ nono obiit dominus

Wladislaus, capellanus fratrum et frater domus.

A III Non.

Remadi $^{m}$ episcopi et confessoris

4 XII B II Non.

Marcelli martyris 


$\begin{array}{rlll} & \text { II } & \text { C Non. } \\ 6 & & \text { D VIII Id. } \\ {[s .68]} & & \text { X } & \text { E VII Id. } \\ 8 & & \text { F VI Id. } \\ 9 & \text { XVIII } & \text { G V Id. } \\ 10 & \text { VII } & \text { A IIII Id. } \\ 11 & & \text { B III Id. }\end{array}$

[s. 69] $12 \quad$ XV $\quad$ C II Id.

13 IIII D Id.

14 E XVIII KI.

15 XII F XVII Kl.

16 I G XVI Kl.

17 A XV Kl.

18 IX B XIV KI.

\section{[s. 70] $19 \quad$ C XIII KI. \\ 20 XVIII D XII KI.}

21 VI E XI KI.
Anno Domini $\mathrm{M}^{\circ} 4^{\circ}$ VII obiit Andreas Wirzing, pater et promotor specialis ${ }^{51}$.

Victorini martyris

Magni confessoris

Regine virginis

Nativitas Sancte Marie Virginis

Gorgonii martyris

Theodardi et Danielis episcoporum et martyrum Prothi et Jacincti martyrum

Anno Domini $\mathrm{M}^{\circ} 4^{\circ} \mathrm{XXV}$ obiit domina Gennadia alias Eneda, benefactrix specialis domus $^{52}$.

Juvencii martyris

Philipi martyris

Exaltacio Sancte Crucis, Cornelii et Cipriani martyrum

Anno Domini $\mathrm{M}^{\circ} 4^{\circ} \mathrm{LII}$ obiit dominus Nicolaus Teschner, frater domus, altarista in capella sancti Stanislai martyris ${ }^{53}$.

Nicomedis martyris

Lucie virginis

Lamberti episcopi et martyris

Florentini martyris

Anno Domini $\mathrm{M}^{\circ} \mathrm{CCCC}^{\circ} 4^{\circ}$ primo obiit Nicolaus Beliczer, benefactor domus, qui vendidit domum suam duobus altaristis, Johanni Scho $^{e}$ nto ${ }^{e}$ et Jacobo Zilbir, in perpetuum ${ }^{54}$. Goerici episcopi

Vigilia

Anno Domini $\mathrm{M}^{\circ} 4^{\circ}$ XXXIX obiit domina Katherina Wolynne benefactrix domus.

Eodem die anno Domini $\mathrm{M}^{\circ} 4^{\circ} 7^{\circ}$ II obiit dominus Nicolaus Shiroff, altarista Marie Magdalene, frater et benefactor domus ${ }^{55}$.

Anno Domini $\mathrm{M}^{\circ} 4^{\circ} 6^{\circ}$ primo XXI mensis Septembris Zophia regina Polonie decessit de hac vita, id est in sancti Mathie [sic] $\operatorname{apostoli}^{56}$.

\section{Mathei apostoli et evangeliste}

Anno Domini $\mathrm{M}^{\circ} 4^{\circ}$ XXXIX obiit dominus Martinus, frater domus.

Mauricii et sociorum eius

Anno Domini $\mathrm{M}^{\circ} 4^{\circ} 60$ die Lune XXII Septembris reverendus in Christo pater dominus 
Thomas episcopus Cracoviensis, decretorum doctor et sacre theologie professor, mortuus est, id est in die sancti Mauricii ${ }^{57}$.

23 XIIII G IX Kl.

24 III A VIII Kl.

[s. 71] 25

26 XI C VI KI.

27 XIX D V Kl.

28 E IIII Kl.

29 VIII F III Kl.

30 G II Kl.
Tecle virginis, Lini pape et martyris

Ruchberti episcopi

Firmicii martyris

Cypriani episcopi et martyris

Translacio sancti Stanislai martyris. Cosme et Damiani martyrum

Wenceslai martyris

Memoria sancti Michaelis

Jeronimi presbiteri

[s. 72]

October habet dies XXXI, lunaciones XXIX

$\begin{array}{lll}1 & \text { XVI } & \text { A Kl. } \\ 2 & \text { V } & \text { B VI Non. } \\ 3 & \text { XIIII } & \text { C V Non. } \\ 4 & \text { II } & \text { D IIII Non. } \\ 5 & & \text { E III Non. } \\ 6 & \mathbf{X} & \text { F II Non. }\end{array}$

[s. 73] 7 G Non.

$8 \quad$ XVIII A VIII Id.

Remigii episcopi et confessoris

Leodagarii martyris

Duorum Evaldorum presbiterorum

Francisci confessoris

Martiani martyris

Caprasii martyris

Marci pape

$<$ Anno Domini 1514 obiit dominus Mathias

Hyrsz, confrater domus, qui legavit fratribus Bibliam sentenciarum.>

Demetrii martyris

Dyonisii episcopi sociorumque eius Anno Domini $\mathrm{M}^{\circ} 4^{\circ}$ XXII obiit dominus

Martinus de Pilsna, benefactor domus.

10 C VI Id.

Gereonis sociorumque eius

Anno Domini $\mathrm{M}^{\circ} 4^{\circ}$ LIIII obiit dominus

Paulus de Czenstochowa, altarista et benefactor domus, qui legavit domui et fratribus octuaginta marcas pro anniversario.

$\begin{array}{lll}11 & \text { XV } & \text { D V Id. } \\ 12 & \text { III } & \text { E IIII Id. }\end{array}$

Sanctini martyris

Burchardi confessoris

Anno Domini $\mathrm{M}^{\circ} 4^{\circ}$ XXX VII obiit dominus Andreas de Becz, confrater et benefactor domus $^{58}$.

Eodem die obiit Dorothea Zilberin ${ }^{59}$.
[s. 74] 13
F III Id.
$14 \quad$ XII
G II Id.
15
A Id.

Athanasii episcopi

Callixti pape et martyris

Sanctorum Maurorum, Hedwigis

Anno Domini $\mathrm{M}^{\circ} \mathrm{CCC}^{\circ} \mathrm{LXXXII}$ obiit magister Johannes Kirchan. 
Galli abbatis

Anno Domini $\mathrm{M}^{\circ} 4^{\circ} \mathrm{X}$ obiit dominus Wenceslaus Parvus.

17 IX C XVI KI. $\quad$ Florencii

18 D XV Kl.

Luce ewangeliste

[s. 75] 19 XVII E XIIII KI.

Januarii sociorumque eius

20 VI F XIII KI.

$21 \quad$ G XII KI.

22 XIIII A XI KI.

23 III B X Kl.

$24 \quad$ C IX KI.

25 XI D VIII KI.

[s. 76] 26 XIX E VII KI.

27 F VI KI.

28 VIII G V KI.

29 A IIII KI.

30 XVI B III KI.

[s. 77] $31 \quad$ V $\quad$ C II Kl.

Caprasii, translacio sancti Adalberti episcopi et martyris

\section{Milia Virginum}

Seueri episcopi

Seuerini episcopi

Columbani episcopi

Crispini et Crispiniani

Vedasti et Amandi episcoporum

Vigilia

Simonis et Jude

Narcissi episcopi et martyris

Saturnini martyris

$<<<<$ Anno Domini 1672 die 30 Octobris reverendus Martinus Głowicz, confrater domus obiit. Quale beneficium confratribus domus contulerit, vide infra inter mortuos fratres. $\gg>>$

November habet dies XXX, lunaciones XXX

D Kl.

Festivitas Omnium Sanctorum

XIII E IIII Non.

Commemoracio fidelium animarum

F III Non. G II Non.

Huberti episcopi et confessoris

A Non.

Modeste virginis

B VIII Id.

Felicis presbiteri

XVIII

C VII Id.

Leonardi confessoris

VII D VI Id.

Willibrordi episcopi et confessoris

Quatuor coronatorum

Anno Domini $\mathrm{M}^{\circ} 4^{\circ}$ XXXI obiit dominus

Nicolaus sacristianus ${ }^{60}$.

$9 \quad$ E V Id.

10 XV F IV Id.

11 IIII G III Id.

Teodori martyris

Leonis pape

Martini episcopi et confessoris

Anno Domini $\mathrm{M}^{\circ} 4$ XXXIX obiit dominus

Mathias de Myedwyedz ${ }^{61}$, benefactor domus.

A II Id.

Cuniberti episcopi et confessoris

13 XII B Id.

14 I C XVIII KI.

Bricii episcopi et confessoris

Clementini martyris

15 D XVII KI.

Fundarii confessoris 


\begin{tabular}{|c|c|c|c|c|}
\hline & 16 & IX & E XVI Kl. & Othmari abbatis \\
\hline & 17 & & F XV Kl. & Aniani confessoris \\
\hline \multirow[t]{10}{*}{ [s. 80] } & 18 & XVII & G XIIII KI. & Octava sancti Martini \\
\hline & 19 & VI & A XIII Kl. & Sancte Elisabeth \\
\hline & 20 & & B XII KI. & Ponciani martyris \\
\hline & & & & Anno Domini $\mathrm{M}^{\circ} 4^{\circ} 5^{\circ}$ obiit dominus Nicolaus \\
\hline & & & & Czanser, confrater ac benefactor huius domus ${ }^{62}$. \\
\hline & 21 & XIIII & C XI Kl. & Columbani \\
\hline & & & & Anno Domini $\mathrm{M}^{\circ} 4^{\circ} \mathrm{LXI}$ obiit dominus Clemens \\
\hline & & & & Czichy, altarista sancte Agnetis, confrater domus. \\
\hline & 22 & III & D X Kl. & Cecilie virginis \\
\hline & 23 & & E IX Kl. & Clementis pape et martyris \\
\hline \multirow[t]{7}{*}{ [s.81] } & 24 & $\mathbf{X I}$ & F VIII KI. & Crisogoni martyris \\
\hline & 25 & XIX & G VII Kl. & Katherine virginis \\
\hline & 26 & & A VI Kl. & Basulii confessoris \\
\hline & 27 & VIII & B V Kl. & Maximini confessoris \\
\hline & 28 & & C IV Kl. & Julii et Euzebii \\
\hline & 29 & XVI & D III Kl. & Vigilia \\
\hline & 30 & $\mathbf{V}$ & E II Kl. & Andree apostoli \\
\hline
\end{tabular}

December habet dies XXXI, lunaciones XXIX

$\begin{array}{llll} & & & \text { F Kl. Decen } \\ 2 & \text { XIII } & \text { G IIII Non. } \\ 3 & & \text { A III Non. } \\ & & \text { X } & \text { B II Non. } \\ & \text { C Non. } \\ 5 \text { s. 83] } & & & \text { C N } \\ 6 & \text { XVIII } & \text { D VIII Id. } \\ 7 & \text { VII } & \text { E VII Id. } \\ 8 & & \text { F VI Id. } \\ 9 & \text { XV } & \text { G V Id. }\end{array}$

$\begin{array}{rll}10 & \text { IIII } & \text { A III Id. } \\ {[s .84] 11} & & \text { B III Id. } \\ 12 & \text { XII } & \text { C II Id. } \\ 13 & \text { I } & \text { D Id. } \\ 14 & & \text { E XIX Kl. } \\ 15 & \text { IX } & \text { F XVIII Kl. } \\ 16 & & \text { G XVII KI. } \\ 17 & \text { XVII } & \text { A XVI Kl. } \\ 18 & \text { VI } & \text { B XV KI. }\end{array}$

Aggerici episcopi et martyris

Longini martyris

Cassiani martyris

Barbare virginis

Dalmacii martyris

Nicolai episcopi et confessoris

Octava sancti Andree

Concepcionis Sancte Marie

Leucadie virginis

Anno Domini $\mathrm{M}^{\circ} 4^{\circ}$ XXXXVII obiit dominus Johannes Croker, altarista beatorum Petri et Pauli, frater et benefactor domus ${ }^{63}$.

Eulalie virginis

Damasii pape

Hermogonis confessoris

Lucie virginis

Nicasii episcopi

Maximini presbiteris

Valentis martyris

Ignacii martyris

Honorati martyris

Anno Domini $\mathrm{M}^{\circ} 4^{\circ}$ LXVI obiit dominus Stanislaus, cantor et altarista fraterque domus altaristarum. 
Nemesii martyris

Anno Domini $\mathrm{M}^{\circ} 4^{\circ}$ XXIX obiit magister

Nicolaus Goltberg, predicator ecclesie Sancte Marie $^{64}$.

20 XIIII D XIII KI.

Vigilia

21 III E XIII [sic] KI.

Thome apostoli

22 F XI KI.

[s. 86] $23 \quad$ XI $\quad$ G X Kl.

24 XIX A IX KI.

25 B VIII KI.

Triginta martyrum

Victorie virginis

Vigilia Domini nostri Jesu Christi

Nativitas Domini nostri Jesu Christi

26 VIII C VII KI.

27 D VI KI.

Obiit dominus Georgius de Wyeliczka ${ }^{65}$.

Stephani protomartyris

Johannis apostoli et ewangeliste

Obiit dominus Johannes Pitczin ${ }^{66}$.

Innocentum martyrum

Thome episcopi et martyris

Perpetui confessoris

31 II G III K.

Siluestri pape et confessoris

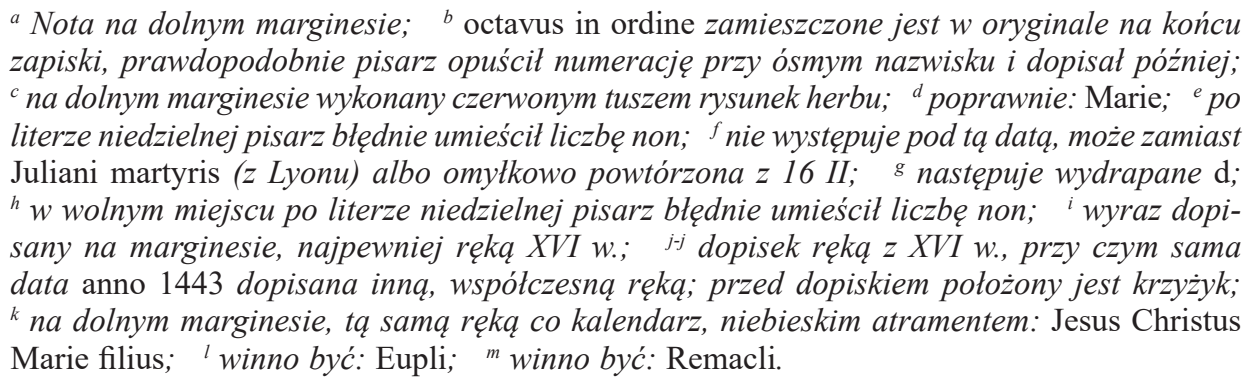

${ }^{1}$ Najpewniej Marcin z Bochni, wystęuje jako altarysta mariacki 1469 (APM, dok. nr 47) oraz altarysta oltarza św. św. Piotra i Pawła 1474-1480 (LB II, s. 4); ${ }^{2}$ wymienieni w zapisce rajcy (notowani w źródtach miejskich $w$ tej samej kolejności) tworzyli skład rady urzędującej w 1397 r. (NKRK II, s. 254); ${ }^{3}$ Kasper z Domnowa w Prusach (Domnau), syn Jana, zm. 1477, immatrykulowany na Uniwersytecie Krakowskim 1455, bakałarz 1458, mistrz sztuk wyzwolonych 1471 (Najstarsza księga promocji Wydziału Sztuk Uniwersytetu Krakowskiego z lat 1402-1541, wyd. A. Gąsiorowski, T. Jurek, I. Skierska, Warszawa 2011, s. 222 [58/41], 234 [71/1]); ${ }^{4}$ Mikołaj Tauchan z Nysy (1441-1502), syn rajcy nyskiego Pawła, od 1457 studiowat na Uniwersytecie Krakowskim, 1459 bakałarz, 1462 magister sztuk, następnie jako extraneus wyktadał na Wydziale Sztuk, studiujac jednocześnie prawo kanoniczne, nauke zwieńczyt w 1474 doktoratem dekretów, w 1478 przenióst się do Wrocławia, gdzie obją kierownictwo szkoty św. Marii Magdaleny oraz kanonię w kapitule katedralnej; 1479-1494 oficjat i wikariusz generalny biskupa wroctawskiego, związany z krakowskim kręgiem humanistycznym (Profesorowie Wydziału Prawa Uniwersytetu Jagiellońskiego, t. I, Kraków 2015, s. 289-290); ${ }^{5}$ Bernard z Nysy, 1484 notowany jako profesor teologii, kanonik wrocławski i św. Floriana w Kleparzu, kolegiat większy Uniwersytetu Krakowskiego (KDMK II, nr 705); ${ }^{6}$ Jakub Zilber, zm. 1408, jako kapłan kościoła Mariackiego wymieniony w dyplomie z 1397 r., moca którego altaryści mariaccy przekazali zarzad nad zamieszkiwanym przez siebie domem radzie miejskiej (KDKK II, $n \mathrm{r}$ 425); 7 Jan ze Skawiny, zm. 1447, altarysta ottarza św. Katarzyny 1433 (ZDKK II, 
nr 325), altarysta mariacki 1446 (CAS 1441-1450, $n r$ 481); ${ }^{8}$ Hanek Peterman, zm. 1396, mieszczanin krakowski, notowany $w$ rachunkach miejskich 1390-1395 (NKRK II, s. 341); ${ }^{9}$ Mikałaj Gundrami, zm. 1416, notowany w rachunkach miejskich w latach 1395-1406, od 1400 jako altarysta mariacki (NKRK II, s. 343); ${ }^{10}$ Piotr Grot z Konstancina, zm. 1431, altarysta mariacki 1428, rada miasta Krakowa potwierdzita mu 2 X 1428 sprzedaż na wyderkauf 8 grzywien czynszu z postrzygalni sukna za 160 grzywien (KDMK I, nr m; KDMK II, $n r$ n, 511);

${ }^{11}$ Stanistaw z Bytomia, zm. 1456, altarysta mariacki 1441-1445 (CAS 1441-1450, nr 91, 259, 333, 410, 412); 12 może identyczny z Piotrem Godfridi, występujacym jako altarysta mariacki 1397 (KDMK II, nr 399); ${ }^{13}$ Michał z Krosna, zm. 1474, syn mieszczanina Wawrzyńca z Krosna, student w Krakowie i Lipsku, doktor dekretów (przed czerwcem 1444), dwukrotny dziekan Wydziału Prawa (1457, 1465/1467), członek elitarnego bractwa Panny Marii przy kościele Mariackim (Profesorowie, s. 272-273); ${ }^{14}$ Klaus Kezinger, zm. 1445, mieszczanin krakowski, rajca 1412-1443 (Starz. nr 194); ${ }^{15}$ Zbigniew Oleśnicki (1389-1455) biskup krakowski 1423-1455, kardynat od 1449, w nocie błędnie podane zostaty lata kardynalatu, data śmierci potwierdzona w innych źródłach; ${ }^{16}$ może identyczny z Janem Kyzewetirem, mieszczaninem krakowskim 1367 (KDMK II, nr 385); ${ }^{17}$ Maciej z Pyzdr, zm. 1445, altarysta oltarza św. Agnieszki od 1440 (CDUJ I, nr 103); ${ }^{18}$ Maciej, zm. 1440, mieszczanin krakowski, starszy cechu kapeluszników 1430 i 1435 (CA nr 270, 312); ${ }^{19}$ może identyczny z Danielem, zm. przed 5 V 1458, występujacym jako familiaris Zbigniewa Oleśnickiego, plebanem w Tuchowie (BP $V I, n r 1283,1305,1312,1459)$, wcześniej odnotowanym 1433 jako altarysta oltarza św. św. Feliksa i Adaukta (ZDKK II, nr 325); ${ }^{20}$ Marcin z Miedźna (koło Kłobucka), może identyczny z Marcinem, zm. 1465, altarystą ołatarza św. Aleksego 1439 i 1458 (CA nr 340, 513);

${ }^{21}$ Jan Czeyskendorf z Krakowa, zm. 1484, altarysta oltarza Krzyża Świętego 1474-1480 (LB II, s. 3); ${ }^{22}$ Piotr z Tyczyna, zm. 1436, altarysta ottarza św. św. Antoniego i Doroty 1433 (ZDKK II, nr 325); ${ }^{23}$ Pawet z Ujazdu, zm. 1479, altarysta oltarza Wniebowzięcia NMP 1443 (ZDKK II, nr 443); ${ }^{24}$ Jan Łukaszowy, zm. 1476, altarysta mariacki 1469 (APM, dok. $n$ r 47); ${ }^{25}$ Katarzyna, zm. 1390, żona Mikołaja Belicza, mieszczanina krakowskiego, rajcy 1395 (Starz. nr 165); ${ }^{26}$ Piotr Kaldherberg, zm. przed 1424, mieszczanin krakowski, rajca 1417-1421 (Starz. $n r$ 207); ${ }^{27}$ Mikołaj syn mtynarza (molendinatoris) zwany Capella, zm. 1457, altarysta ołtarza św. św. Anny i Elżbiety 1433, altarysta mariacki 1441 (ZDKK II, $n r$ 325, 425); ${ }^{28}$ Jan Bartosz, zm. 1463, altarysta mariacki 1454 i 1461 (altarysta ottarza mistrza Szczepana Leypnigera), 1461 rada miejska sprzedała mu na wyderkauf 18 grzywien czynszu na domu kuśnierzy za 514 florenów, które przekazano następnie królowi na prowadzenie wojny z Zakonem (KDMK II, nr 439, 559); ${ }^{29}$ Mikołaj Kerber altarysta mariacki 1431 (KDMK II, nr 517); ${ }^{30}$ Jan Lutkowic z Brzezia (ok. 1405-1471), administrator arcybiskupstwa gnieźnieńskiego 1453, biskup kujawski 1463-1464 i krakowski od 1464, data śmierci potwierdzona w innych źródtach;

${ }^{31}$ Jan Schönthör, zm. 1407, dzięki jego legatowi wysokości 80 grzywien zakupiony zostat dom altarystów przy Małym Rynku; 32 Władysław Jagiełlo, zm. 1434, król Polski od 1386, data śmierci potwierdzona w innych źródłach; ${ }^{33}$ Kaspar Krugel, zm. 1417, mieszczanin krakowski, rajca 1393-1412 (Starz. $n r$ 194); ${ }^{34}$ Jan Zebenwirt, zm. 1443, mieszczanin krakowski, rajca 1419-1425 (Starz. nr 194); ${ }^{35}$ Mikołaj Czypser, zm. 1439, wikariusz mariacki 1419 (KDMK II, nr 406); ${ }^{36}$ może identyczny z przyjmujacymi prawo miejskie w Krakowie Piotrem z Biecza 1400 lub Piotrem z Biecza czapnikiem 1401 (KPPM, nr 1143, 1248); ${ }^{37}$ trzesienie ziemi poświadczone przez kilka niezależnych od siebie źródel, w tym kalendarz krakowski (M. H. Malewicz, Zjawiska przyrodnicze w relacjach dziejopisarzy polskiego średniowiecza, Wrocław 1980, s. 94); ${ }^{38}$ Jan Teszner starszy, zm. 1459, mieszczanin krakowski, rajca 14391458 (Starz. $n r$ 242); ${ }^{39}$ zaćmienie stońca odnotowane jedynie w Rocznikach Jana Dtugosza z podobnym, ale mniej dokładnym określeniem czasu: terciarum hora (M. H. Malewicz, Zjawiska, s. 98); ${ }^{40}$ Jan, zm. 1476, zakrystianin mariacki 1469 (APM, dok. nr 47);

${ }^{41}$ wspomniane $w$ zapisce statuty $i$ katalog konfratrów znajdują się w tym samym rękopisie co publikowany kalendarz i nekrolog; ${ }^{42}$ Gizeler, zm. 1400, mieszczanin krakowski, rajca 13911396 (Starz. nr 194); ${ }^{43}$ Jerzy z Wińska (Winzig) na Śląsku, altarysta ołtarza św. Hieronima 
1474-1480 (LB II, s. 3); ${ }^{44}$ Mikołaj Falkenberg, zm. 1438, altarysta oltarza Wniebowzięcia NMP w kaplicy św. Barbary 1433 (ZDKK II, nr 325); ${ }^{45}$ Katarzyna Krancz, zm. 1407, mieszczka krakowska, 1395 wdowa po rajcy Janie Kranczu (ASC nr 2101; Starz. nr 150); ${ }^{46}$ Jadwiga Andegaweńska (1374-1399), najmłodsza córka Ludwika Węgierskiego i Elżbiety Bośniaczki, król Polski od 1384, od 1386 żona Władystawa Jagietly, święta, data śmierci potwierdzona w innych źródłach; ${ }^{47}$ Mikołaj Kromer, zm. 1422, mieszczanin krakowski 1414 (KDMK II, s. 528, $\mathrm{nr}$ g); ${ }^{48}$ może identyczny z Mikołajem synem Jana Howera z Krakowa, immatrykulowanym w Uniwersytecie Krakowskim 1430 (Metryka I, s. 150 [30e/072]); ${ }^{49}$ Mikołaj Rolla z Ujazdu, zm. 1430, altarysta mariacki 1425, uposażył ołtarz św. Marii Magdaleny czynszem rocznym 10 grzywien z Małej Wagi oraz domu kuśnierzy, pobieranym w zamian za udzielona radzie pożyczke 200 grzywien (KDMK II, $n r$ 510); ${ }^{50}$ mistrz Szczepan Leipniger, zm. 1459, w 1437 jako eltirher czu Beuthom otrzymat od rady miejskiej roczny czynsz 12 grzywien z postrzygalni sukna oraz fuldkamer w zamian za pożyczkę 343 florenów wegierskich, 1441 odstapit ten czynsz klasztorowi kanoników regularnych Bożego Ciała w Kazimierzu; 1445 rada sprzedała mu z prawem odkupu za 300 grzywien czynsz 18 grzywien z domu kuśnierzy (KDMK II, $n r$ 527, 546);

${ }^{51}$ Andrzej Wierzynek, zm. 1406, mieszcznin krakowski, rajca 1378-1406 (Starz. nr 150); ${ }^{52}$ Eneda, zm. 1425, wdowa po mieszczaninie krakowskim Mikołaju Münzschreiberze (ZDKK II, nr 257); ${ }^{53}$ Mikołaj Teszner, zm. 1452, syn mieszczanina krakowskiego i rajcy Jana Tesznera starszego, brat Stanisława, wystepuje 1446 (KDMK II, $n r$ 428); ${ }^{54}$ Mikołaj Bielicz, mieszczanin krakowski, rajca 1395 (Starz. $n r$ 150); ${ }^{55}$ może identyczny z Mikołajem Stroffem altarysta mariackim 1463 (BP VI, nr 1855); ${ }^{56}$ Zofia Holszańska, zm. 1461, księżniczka litewska, córka Andrzeja Holszańskiego i księżniczki druckiej Aleksandry, czwarta żona Władysława Jagietty (od 1422), data śmierci potwierdzona w innych źródłach; ${ }^{57}$ Tomasz ze Strzempinia (13981460), doktor prawa kanonicznego 1432, mistrz teologii 1443, trzykrotny rektor Uniwersytetu Krakowskiego, od 1455 biskup krakowski, data śmierci potwierdzona w innych źródłach; ${ }^{58}$ Andrzej z Biecza, zm. 1437, altarysta mariacki 1425, altarysta ottarza św. Stanisława 1433 (ZDKK II, nr 258, 325); ${ }^{59}$ Dorota Zilberyn mieszczka krakowska 1390-1392 (ASC nr 1290, 1577); ${ }^{60}$ może identyczny z Mikołajem spowiednikiem, zwanym także de sancta Anna, występujacym 1419 i 1425 (KDKK II, nr 406; ZDKK II, nr 257);

${ }^{61}$ znany jest tylko Maciej sottys Niedźwiedzia w par. Mszana 1469, może syn odnotowanego w nekrologu mariackim (Kraków, Archiwum Narodowe, Teutonicalia 3, s. 420 - za informację serdecznie dziękuję Panu dr. Waldemarowi Bukowskiemu); ${ }^{62}$ Mikołaj Czanser, zm. 1450, wikariusz mariacki i altarysta oltarza Wniebowzięcia NMP 1425 i 1430 (ZDKK II, $n r$ 256, 258, 296-297); ${ }^{63}$ Jan Kroker, zm. 1447, altarysta oltarza św. św. Piotra i Pawła 1433 (ZDKK II, nr 325); ${ }^{64}$ mistrz Mikołaj Goldberg, zm. 1429, kaznodzieja mariacki 1425 (ZDKK II, $n$ r 262); ${ }^{65}$ może identyczny z Jerzym z Wieliczki szewcem przyjmującym prawo miejskie w Krakowie 1472 (KPPM nr 7410); ${ }^{66}$ Jan Pitschen mieszczanin krakowski, starszy - rajca 1393-1401, lub młodszy - rajca 1441-1457 (Starz. nr 161, 247).

\section{Katalog altarystów i benefaktorów domu altarystów kościoła Mariackiego w Krakowie}

[s. 137] Isti sunt altariste primi domus altaristarum ${ }^{a}$.

Item primus altarista dominus Johannes $\mathrm{Scho}^{\mathrm{e}}$ nto ${ }^{\mathrm{e}} \mathrm{r}^{l}$, qui pro primo fundamentum iacens, LXXX marcas grossorum latorum domino Jacobo $\mathrm{Zilbir}^{2}$ confratri domelle prefate legando commisit pro domo ampliori ipsis altaristis inhabitanda convenienciori protunc et alias infuturum dum et quando quomodiose huiusmodi venalis ocurreret comparanda, si quando dominus alicui iterum ad hoc ipsum similiter opus aliquid inspiraret faciendum. Inspiratus deinde idem dominus Jacobus Zilbir dimittens peculium suum bonaque propria, quibus aliqualiter abundaverat, ad LXXX marcas prefatas 
domini Johannis Schoento ${ }^{e}$ letabunde adiiciens a Nicolao Belycer ${ }^{3}$ et Katherina uxore ipsius $^{4}$ pariter domum primam versus plateam Walve Nove supradicte fundamentaliter iacentem, quia tunc in Cracovia valde domus erant preciose, pro summa notabili ad laudem Dei pariter et gloriam hilariter atque gaudenter comparuit. Isti duo viri domum altaristarum fundaverunt.

Item alii altariste:

Dominus Petrus ${ }^{5}$ X Milia Militum.

Dominus Johannes Tassonis ${ }^{6}$ sanctorum Petri et Pauli apostolorum.

Dominus Petrus decanus de Ticzin ${ }^{7}$ sancti Anthonii.

Magister Johannes Kirchan obiit M CCC LXXXII [w nekrologu pod 15 X].

Dominus Geyseler ${ }^{8}$ frater domus obiit $\mathrm{M}[\mathrm{C}] \mathrm{CCC}^{\circ}$.

Dominus Nicolaus $\mathrm{Rol}^{9}$ frater domus obiit M 4 XXX.

Dominus Nicolaus de Germer ${ }^{10}$ predicator obiit M 4 XVI.

Dominus Jacobus Zilbir primus erector domus obiit M 4 VIII.

Dominus Symon ${ }^{l l}$ quondam rector scolarum ecclesie sancte Anne.

Dominus Johannes Croker ${ }^{12}$, sanctorum Petri et Pauli, benefactor domus 14 XLVII. [s. 138] Item alii:

Dominus Petrus Groth ${ }^{13}$ magnus benefactor domus obiit 14 XXXI.

Dominus Nicolaus Gundrami ${ }^{14}$ obiit $\mathrm{M}^{0} 4$ XVI.

Dominus Nicolaus Romanus obiit $\mathrm{M}^{\circ} 4$ IX.

Dominus Petrus de Ticzin obiit $\mathrm{M}^{\circ} 4$ XXXVI.

Dominus Johannes $\mathrm{So}^{e}$ ntho $\mathrm{e}$ primus fundator domus obiit $\mathrm{M}^{\circ}[\mathrm{C}] \mathrm{CCC}^{\circ} \mathrm{VII}$.

Dominus Nicolaus Kerber $^{15}$ frater domus obiit $\mathrm{M}^{\circ} 4$ XXXI.

Dominus Nicolaus Falkenberg ${ }^{16}$ frater domus obiit $\mathrm{M}^{\circ} 4$ XXXVIII.

Dominus Nicolaus Czypszer ${ }^{17}$ frater domus obiit $\mathrm{M}^{\circ} 4$ XXXIX.

Dominus Martinus frater Capelle frater domus obiit $\mathrm{M}^{\circ} 4$ XXXV.

Magister Nicolaus Goltberg ${ }^{18}$ frater domus obiit $\mathrm{M}^{\circ} 4$ XXXIX [recte: 1429 , jak w nekrologu pod 19 XII].

Dominus Mathias de Peyzer ${ }^{19}$ frater domus obiit $\mathrm{M}^{0} 445$.

Dominus Gothfridus frater domus obiit $\mathrm{M}^{\circ} 4$ XXXIX [recte: 1453, jak w nekrologu pod $21 \mathrm{VII}]$.

Dominus Wenceslaus predicator, frater domus obiit anno $\mathrm{XC}^{\circ}$.

Dominus Wladislaus capellanus fratrum, frater domus obiit M 439.

Dominus Martinus Niger frater domus obiit $\mathrm{M}^{\circ} 4$ XXXIX.

Dominus Johannes Skawinsky ${ }^{20}$ frater domus obiit $\mathrm{M}^{\circ} 4$ XLVII.

Dominus Nicolaus Thesner ${ }^{21}$ frater domus obiit $\mathrm{M}^{\circ} 4$ LII.

Dominus Martinus de Pilsna benefactor domus obiit 14 XXII.

Dominus Andreas de $\mathrm{Becz}^{22}$ benefactor domus obiit 14 XXXVII.

Magister Johannes Kirchan frater domus obiit $\mathrm{M}^{\circ} 3^{\circ} \mathrm{LXXXII}^{b}$.

Dominus Wenceslaus Parvus frater domus obiit M 4 X.

Honestus vir Johannes Zebenwirt ${ }^{23}$ magnus benefactor et ampliator istius domus obiit $\mathrm{M}^{\circ} 4$ XLIII.

Dominus Nicolaus sacristianus ${ }^{24}$ frater domus obiit $\mathrm{M}^{\circ} 4$ XXXI.

Dominus Mathias de Myedzwyedz ${ }^{25}$ benefactor domus obiit $\mathrm{M}^{0} 4$ XXXIX.

Dominus Petrus Wolfram ${ }^{26}$ benefactor domus obiit. 
Dominus Johannes Czetirwenge benefactor domus obiit.

[s. 139] Dominus Nicolaus Czanser ${ }^{27}$ frater domus obiit $\mathrm{M}^{\circ} 45^{\circ}$.

Isti alii:

Dominus Daniel ${ }^{28}$ benefactor et frater domus obiit $\mathrm{M}^{\circ} 4$ LVIII.

Dominus Nicolaus Capella ${ }^{29}$ benefactor domus et frater noster obiit 14 LVII.

Dominus Clemens de Zathor altarista Petri et Pauli, frater domus obiit 14 LIIII.

Dominus Paulus de Czestochowa benefactor domus obiit 14 LIIII.

Dominus Stanislaus cantor, frater domus obiit $\mathrm{M}^{\circ} 4 \mathrm{LVI}^{\circ}$ [recte: 1466, jak w nekrologu pod $18 \mathrm{XII}$.

Dominus Nicolaus Ympner frater domus obiit $\mathrm{M}^{\circ} 4$ LXII.

Magister Nicolaus $\mathrm{Ho}^{\mathrm{e}}$ wer $^{30}$ frater domus obiit $\mathrm{M}^{\mathrm{0}} 4 \mathrm{LV}$.

Magister Stephanus Leypniger ${ }^{31}$ benefactor domus obiit 14 LIX.

Dominus Martinus Striczek ${ }^{32}$ frater domus obiit $\mathrm{M}^{\circ} 46 \mathrm{~V}$.

Dominus Martinus Gleywicz frater domus obiit $\mathrm{M}^{\circ} 4 \mathrm{LX}$.

Dominus Clemens Czychi frater domus obiit $\mathrm{M}^{\circ} 461$.

Dominus Allexander frater domus obiit $\mathrm{M}^{\circ} 46$ VII.

Dominus Johannes Barthos ${ }^{33}$ frater domus obiit $\mathrm{M}^{\mathrm{o}} 46$ III.

Dominus Nicolaus Syroff frater domus obiit $\mathrm{M}^{\circ} 47$ II.

Dominus Johannes Luce ${ }^{34}$ benefactor domus obiit $\mathrm{M}^{\mathrm{0}} 476$.

Magister Michael de Crosna decretorum doctor ${ }^{35}$, frater domus obiit $\mathrm{M}^{\mathrm{0}} 4$ LXXIIII.

Dominus Gregorius de Czeskowicze obiit $\mathrm{M}^{0} 475$.

Magister Caspar de Dambnow ${ }^{36}$ benefactor domus obiit M $^{\circ} 4$ LXXVII.

Dominus Paulus de Wyasd ${ }^{37}$ frater domus obiit $\mathrm{M}^{\circ} 47^{\circ} 9$.

Dominus Georgius de Winczig ${ }^{38}$ benefactor domus obiit M $^{\circ} 4$ LXXXII.

Dominus Nicolaus cantor, altarista, frater domus obiit $\mathrm{M}^{\circ} 48$ III.

Dominus Johannes Andree alias Czeyskendorf ${ }^{39}$ confrater domus obiit $\mathrm{M}^{\mathrm{o}} 4^{\circ} 8$ IIII.

Nicolaus Constantini altarista domus obiit 1488.

Martinus de Bochna ${ }^{40}$ altarista domus obiit 1486.

Petrus de Schawyna altarista domus 1488.

Doctor Clemens altarista domus et predicator ad sanctam Barbaram 1489.

Cristanus de Tarnow altarista domus obiit anno Domini 1498.

[s. 140] Andres Wroblowsky confrater domus et benefactor centum florenos reliquit in moneta.

Jacobus monachus 1496 confrater domus.

Johannes Wolny frater domus 1498.

Georgius Landeszhut confrater sacristianus 1502.

Bartholomeus de Byecz confrater domus 150 quarto quinta Aprilis [5 IV].

Johannes Schepcz anno Christi 150 quarto feria sexta post Vistiacionis Marie [5 $\mathrm{VII}]$.

Paulus de Wogstadt confrater domus obiit 1504 feria secunda ante Margarethe [8 $V I I]$.

Gregorius de Posnania confrater domus obiit anno Domini 1505 ipso die sancti Marci [25 IV].

Valentinus de Byecz obiit 1506 feria quinta post Epiphaniam [8 I].

Dominus Nicolaus Ditrich obiit in crastino Crispini et Crispiniani martyrum 
[26 X] anno 1506, sacristianus.

Dominus Johannes de Crosna frater domus obiit die Jovis sedecima mensis Marcii [16 III] anno Christi millesimo quingentesimo octavo.

Gregorius de Leysnycz frater domus feria quinta ipso die Sancte Exaltacionis Crucis anno Cristi 1508 [14 IX].

Item Mathias Hresz frater domus obiit anno Domini 1514 in crastino sancti Francisci $\left[\begin{array}{ll}5 & X\end{array}\right]$.

Jacobus Ko ${ }^{\mathrm{e}}$ ler confrater domus obiit anno Domini 1517.

Magister Joannes Grandensz confrater obiit in octava sancti Stefani anno salutis nostre 1513 [9 VIII].

Honorabilis dominus Andreas de Cracovia alias Wazygarnecz frater domus mortuus feria tercia in crastino sancti Valentini [ $15 I I$ ] hora fere secunda noctis future anno Domini millesimo quingentesimo decimo nono. Oretur pro eo.

Joannes Wotka frater ac benefactor domus.

Joannes Sommerfelt frater ac benefactor domus 1526.

[s. 141] Stanislaus de Smygrod sacristianus huius ecclesie obiit anno Domini 1527, benefactor domus.

Joannes Woysta de Trebnicz obiit anno Domini 1528, frater et benefactor domus. Joannes a Turek alias Terelle frater domus.

Joachim a Fredenbergk frater domus 1541.

Paulus Hartigk a Freistad benefactor 1543.

Stanislaus Schal a Craccouia frater domus 1549.

Magister Henricus a Lewtenburgk benefactor.

Vincencius a Cracouia benefactor obiit anno Domini 15482 Marcii.

Matheus Gyssa a Byecz benefactor domus obiit anno 15489 Aprilis.

Magister Georgius a Lignez benefactor domus, qui mansit in domo 45 annis, obiit anno Domini 155017 Decembris.

${ }^{a}$ Na dolnym marginesie: Dominus Johannes Scho ${ }^{\mathrm{e}}$ to ${ }^{\mathrm{e}}$, dominus Jacobus Zilbir, primi erectores; ${ }^{b}$ wpis powtórzony.

${ }^{1}$ Zob. Aneks I, przyp. 31; ${ }^{2}$ zob. Aneks I, przyp. 6; ${ }^{3}$ Mikołaj Belicz mieszczanin krakowski, rajca 1395 (Starz. nr 165); ${ }^{4}$ zob. Aneks I, przyp. 25; ${ }^{5}$ Piotr altarysta mariacki 1397 (KDKK II, $n$ r 425); ${ }^{6}$ Jan Tasso altarysta mariacki 1397 (KDKK II, $n r$ 425); ${ }^{7}$ zob. Aneks I, przyp. 22; ${ }^{8}$ zob. Aneks I, przyp. 42; ${ }^{9}$ zob. Aneks I, przyp. 49; ${ }^{10}$ Mikołaj Germer kaznodzieja mariacki 1397 (KDKK II, nr 425);

${ }^{11}$ Szymon, przed 1397 rektor szkoly parafialnej św. Anny (KDKK II, nr 425); ${ }^{12}$ zob. Aneks I, przyp. 63; ${ }^{13}$ zob. Aneks I, przyp. 10; ${ }^{14}$ zob. Aneks I, przyp. 9; ${ }^{15}$ zob. Aneks I, przyp. 29; ${ }^{16}$ zob. Aneks I, przyp. 44; ${ }^{17}$ zob. Aneks I, przyp. 35; ${ }^{18}$ zob. Aneks I, przyp. 64; ${ }^{19}$ zob. Aneks I, przyp. 17; ${ }^{20}$ zob. Aneks I, przyp. 7;

${ }^{21}$ zob. Aneks I, przyp. 53; ${ }^{22}$ zob. Aneks I, przyp. 58; ${ }^{23}$ zob. Aneks I, przyp. 34; ${ }^{24}$ zob. Aneks I, przyp. 60; ${ }^{25}$ zob. Aneks I, przyp. 61; ${ }^{26}$ Piotr Wolfram, zm. 1428, mieszczanin wolbromski, pisarz w kancelarii Lwowa (do 1407), od 1411 student uniwersytetów w Padwie i Bolonii, nastepnie profesor na Wydziale Prawa Uniwersytetu Krakowskiego, uczestnik soboru $w$ Konstancji, kanonik katedralny poznański i krakowski, ceniony dyplomata $w$ sprawach polsko-krzyżackich, altarysta św. św. Feliksa i Adaukta w kościele św. Barbary (Profesorowie, s. 337-339; M. D. Kowalski, Zapomniany kalendarz-nekrolog kapituły krakowskiej z XV wieku, 
Nasza Przeszłość 87, 1997, s. 135-136); ${ }^{27}$ zob. Aneks I, przyp. 62; ${ }^{28}$ zob. Aneks I, przyp. 19; ${ }^{29}$ zob. Aneks I, przyp. 27; ${ }^{30}$ zob. Aneks I, przyp. 48;

${ }^{31}$ zob. Aneks I, przyp. 50; ${ }^{32}$ zob. Aneks I, przyp. 20; ${ }^{33}$ zob. Aneks I, przyp. 28; ${ }^{34}$ zob. Aneks I, przyp. 24; ${ }^{35}$ zob. Aneks I, przyp. 13; ${ }^{36}$ zob. Aneks I, przyp. 3; ${ }^{37}$ zob. Aneks I, przyp. 23; ${ }^{38}$ zob. Aneks I, przyp. 43; ${ }^{39}$ zob. Aneks I, przyp. 21; ${ }^{40}$ zob. Aneks I, przyp. 1.

\section{BIBLIOGRAFIA}

Chrolonolgia polska, red. B. Włodarski, Warszawa 1957.

Die Benediktinerabtei St. Eucharius-St. Matthias vor Trier, opr. P. Becker, Berlin 1996 (Germania sacra, Neue Folge, t. XXXIV/8).

Die Ochsenkopf- Wasserzeichen, opr. G. Piccard, t. I-III, Stuttgart 1966.

Długopolski E., Katalog kościoła N. P. Maryi w Krakowie, Teka Grona Konserwatorów Galicji Zachodniej 6, 1906.

Friedberg M., Założenie i początkowe dzieje kościoła N. Panny Marji w Krakowie (XIII-XV w.), Rocznik Krakowski 22, 1929 (odbitka, Kraków 1928).

Gąsiorowski S. J., Gąsiorowski Wilhelm, w: Polski słownik biograficzny, t. VII (1948-1958).

Gąsiorowski W., Kościół archiprezbiteralny N.P. Maryi w Krakowie, Kraków 1878.

Grotefend H., Zeitrechnung des deutschen Mittelalters und der Neuzeit, t. I-II, Hannover 1891.

Komorowski W., Średniowieczne domy krakowskie (od lokacji miasta do połowy XVII wieku). Kamienice, pałace miejskie i rezydencje kanonicze. Trwałość modelu gotyckiego w nowożytności, Kraków 2014.

Krzyżanowski S., Sprawozdanie archiwariusza za rok 1892, Kraków 1893.

Kuraś S., Regestrum ecclesiae Cracoviensis. Studium nad powstaniem tzw. Liber beneficiorum Jana Długosza, Warszawa 1966.

Kuraś S., Statuty i przywileje bractwa kapłanów dekanatu zatorskiego 1378-1525, Polonia Sacra 7, 1955.

Malewicz M. H., Zjawiska przyrodnicze w relacjach dziejopisarzy polskiego średniowiecza, Wrocław 1980.

Mitkowski J., Księga zmarłych bractwa Panny Marii w Krakowie (wiek XIV-XVIII), Studia Historyczne 11, 1968.

Piekosiński F., Wybór znaków wodnych z XV stulecia, z. 1, Kraków 1896.

Piwowarczyk E., Dzieje kościoła Mariackiego (XIII-XVI w.), Kraków 2000.

Piwowarczyk E., Fundacje XIV-wiecznych ołtarzy w kościele Mariackim w Krakowie i ich uposażenie do roku 1529, w: Charisteria Tito Górski oblata. Studia i rozprawy ofiarowane profesorowi Tytusowi Górskiemu, Kraków 2003.

Piwowarczyk E., Fundacje XV-wiecznych ołtarzy w kościele Mariackim w Krakowie i ich uposażenie do roku 1529, Folia Historica Cracoviensia 10, 2008.

Rajman J., „Unsere liebe Fraue”. Wspólnota miasta i kościoła w Krakowie w XIV wieku, Średniowiecze Polskie i Powszechne 4 (8), 2012.

Rajman J., Rajcy krakowscy i członkowie ich rodzin w księdze zmarłych bractwa Najświętszej Marii Panny (połowa XIV - koniec XVI wieku), Średniowiecze Polskie i Powszechne 7 (11), 2015.

Rajman J., Żebrak, sługa i rzemieślnik w elitarnym bractwie Najświętszej Marii Panny w Krakowie (XIV - pierwsza połowa XVI wieku), Średniowiecze Polskie i Powszechne 6 (10), 2014.

Ręgorewicz L., Historia Instytutu Technicznego w Krakowie, Kraków 1913.

Sokołowski M., Sprawozdania Komisji do Badania Historii Sztuki w Polsce 5, 1896.

Starzyński M., Krakowska rada miejska w średniowieczu, Kraków 2010.

Starzyński M., Najstarszy dokument hebrajski na ziemiach polskich (1485) i jego thumaczenia, Roczniki Historyczne 83, 2017. 
Wąsowicz H., Kalendarz ksiąg liturgicznych Krakowa do połowy 16. wieku. Studium chronologiczno-typologiczne, Lublin 1995.

Zaremska H., Bractwa w średniowiecznym Krakowie. Studium form społecznych życia religijnego, Wrocław 1977.

Zaremska H., Żydzi w średniowiecznej Polsce. Gmina krakowska, Warszawa 2011.

\section{Materials for the history of altarists of Virgin Mary Church in Cracow in the Middle Ages}

Part 1: The calendar and the necrology, with the catalogue of altarists and benefactors

\section{Summary}

The publication constitutes the first of two planned parts of the critical edition of so far unknown 15th century sources for the history of the house of altarists of the Church of the Assumption of Virgin Mary in Cracow (Kraków, Archiwum Narodowe, Ms. nr 3361). This paper codex, originally bound - which is worth special notice - in a parchment leaf with fragments of the Old Testament Book of Ezekiel written in Hebrew, contains a number of texts related to the functioning (from about 1387) of the house of Virgin Mary Church altarists, where priests serving at the altars of that church were to live together. In 1397 the keeping of that house was taken over by the municipal council of Cracow. It functioned according to almost unchanging rules until the end of the $17^{\text {th }}$ century. The manuscript discussed here (until 1484 written in one hand) contains the calendar and the necrology of the house, relation about its foundation and endowment, statutes, a copy of a charter from the Cracow city council dated 31 December 1397, officia domus, and a catalogue of altarists and benefactors. The first part of the edition contains the calendar and the necrology (with early modern notes) and the catalogue of altarists and benefactors until mid- $16^{\text {th }}$ century. The publication widens the knowledge about the clergy of the most important parish church in Cracow. 